Anna Czypionka*, Katharina Spalek, Isabell Wartenburger and Manfred Krifka

\title{
On the interplay of object animacy and verb type during sentence comprehension in German: ERP evidence from the processing of transitive dative and accusative constructions
}

\author{
https://doi.org/10.1515/ling-2017-0031
}

\begin{abstract}
Comprehension of transitive sentences relies on different kinds of information, like word order, case marking, and animacy contrasts between arguments. When no formal cues like case marking or number congruency are available, a contrast in animacy helps the parser to decide which argument is the grammatical subject and which the object. Processing costs are enhanced when neither formal cues nor animacy contrasts are available in a transitive sentence. We present an ERP study on the comprehension of grammatical transitive German sentences, manipulating animacy contrasts between subjects and objects as well as the verbal case marking pattern. Our study shows strong object animacy effects even in the absence of violations, and in addition suggests that this effect of object animacy is modulated by the verbal case marking pattern.
\end{abstract}

Keywords: sentence comprehension, animacy, case marking, ERP, German

\section{Introduction}

Transitive sentences describe events with one participant doing something to another participant, like Peter is kicking the table. The verb (to kick) denotes the event, and its arguments (Peter and the table) denote the participants in

\footnotetext{
*Corresponding author: Anna Czypionka, Fachbereich Sprachwissenschaft, Universität Konstanz, Fach D 191, Universitätstraße 10, 78457 Konstanz, Germany,

E-mail: anna.czypionka@uni-konstanz.de
}

Katharina Spalek, Department of German Studies and Linguistics, Humboldt-Universität zu Berlin, Unter den Linden 6, 10099 Berlin, Germany, E-mail: katharina.spalek@hu-berlin.de Isabell Wartenburger, Department of Linguistics, Universität Potsdam, Karl-Liebknecht-Strasse 24-25, 14476 Potsdam, Germany, E-mail: isabell.wartenburger@uni-potsdam.de Manfred Krifka, Department of German Studies and Linguistics, Humboldt-Universität zu Berlin, Unter den Linden 6, 10099 Berlin, Germany, E-mail: krifka@rz.hu-berlin.de 
the event. ${ }^{1}$ During sentence comprehension, the parser somehow manages to assign grammatical and thematic roles to the participants - it has to decide which participant is the grammatical subject, which the grammatical object, and who does what to whom in the event described by the verb. To this end, different linguistic cues are used, some of them strictly formal (like number congruency of subjects and verbs, or case marking), others more dependent on the meaning of the words (like animacy of the NPs denoting the participants).

Different lines of research use different definitions of which sentences are "prototypically transitive", assuming that certain types of transitive structures cause smaller processing costs than others. In the psycholinguistic tradition, a prototypically or standard transitive sentence describes an event with one animate participant (like Peter) doing something to an inanimate participant (like the table). This kind of standard transitive sentence is the easiest to process, and deviations from this pattern (sentences describing events with two animate participants) are measurably more difficult to process (e.g., Frisch and Schlesewsky 2001; Trueswell et al. 1994; Weckerly and Kutas 1999; Grewe et al. 2007).

In theoretical linguistics, the definition of prototypical transitivity focuses on the semantic properties that the participants in the event have in the specific situation described by the verb. The distribution of semantic properties influences which participant will be the grammatical subject and which the grammatical object of the sentence (Dowty 1991). Deviations from this kind of prototypical transitivity can lead to unusual argument linking patterns (Belletti and Rizzi 1988; Dowty 1991; Levin 1993), and non-standard case marking of the arguments in case-marking languages like Basque, Georgian, or German (Blume 2000). Below, we will further illustrate the semantic regularities associated with the non-standard case marking pattern, and will explain why we believe they should influence argument processing.

We propose that the effect of having two animate arguments in a sentence should be modulated by the verbal case marking pattern. We present the results of an ERP study on the processing of German transitive sentences, showing animacy effects for verbs with accusative case marking but not for those with dative case marking. In the Discussion, we offer some suggestions as to the linguistic processes possibly reflected by this difference between verb classes.

1 We chose the term "participants in the event" following Dowty (1991). To avoid confusion, we will call the people participating in our experiment proband. 


\subsection{Different kinds of arguments: Object animacy effects}

The animacy of an entity's referent is reflected in many different ways in the languages of the world. Examples include different interrogative pronouns for animate and inanimate entities (who [English] or wer [German] for animates, but what [English] or was [German] for inanimates), or different markings of number (Haspelmath 2013; Corbett 2000; Croft 1990) or case (in DOM languages, see Bossong 1985; Bossong 1991; Naess 2004) for animates and inanimates. In the psycholinguistic tradition, a prototypically transitive sentence has an animate grammatical subject and an inanimate grammatical object. This assumption is motivated by observations from corpus linguistics (e.g., Jäger 2004) and language typology (c.f. Silverstein 1976; Bossong 1985; Dixon 1994; for different examples of the influence of argument animacy on linguistic marking, and Malchukov 2008; for an overview). Deviations from this prototypically transitive pattern are known to increase the processing cost of a sentence. A sentence with two animate arguments (and no morphosyntactic information like case marking or number congruency for grammatical role assignment) is more difficult to process than a sentence with an animate subject and an inanimate object. We will call this increase in processing cost the object animacy effect. Object animacy effects have been found in comprehension studies using eyetracking (Trueswell et al. 1994), fMRI (functional magnetic resonance imaging) (Grewe et al. 2007) and ERP (event related potential) measurements (Frisch and Schlesewsky 2001; Weckerly and Kutas 1999). Object animacy is usually described as increasing the comprehension difficulty of sentences that are already difficult to process, like English object relative clauses (as in Weckerly and Kutas 1999), reduced relative clauses (as in Trueswell et al. 1994), or even clearly ungrammatical, but intelligible clauses (Frisch and Schlesewsky 2001). That is, an object animacy effect is not observed for simple transitive sentences like Mary saw a robin compared to Mary saw a kite, but rather for sentences that are by themselves more computationally demanding (but see Paczynski and Kuperberg 2011, discussed below, for evidence that object animacy effects can be observed in simple sentence structures). For the comprehension of languages other than English, object animacy effects have been reported for simple subordinate clauses rendered difficult by an absence of case marking. For example, Frisch and Schlesewsky (2001) investigated the processing of German transitive sentences with NP-NP-verb word order with event-related potentials. Both NPs were marked with nominative case, making the 
sentences ungrammatical in German. ${ }^{2}$ They found P600 effects on the final verb for all of their incorrect sentences compared to the correct sentences. Only if the sentences had two animate NPs as arguments, did they find an additional N400 effect.

The P600 is a a more positive-going waveform, peaking between 6001000 ms. The P600 amplitude is usually enhanced by increased syntactic processing load (caused by syntactic violations or phrase structure revisions; see, e.g. Hagoort et al. 1993; Osterhout and Holcomb 1992; Kutas et al. 2006). However, it can also be enhanced by violations of argument animacy restrictions of verbs, reviewed in more detail in Kuperberg (2007), and more recently in Paczynski and Kuperberg (2009, 2011, outlined below). The $\mathrm{N} 400$, in contrast, is a negative-going waveform, peaking around $400 \mathrm{~ms}$ after stimulus onset, first reported by Kutas and Hillyard (1980). In psycholinguistic research, enhanced N400 effects were originally found for words that were semantically anomalous in the sentence context. Since then, the N400 has been shown to also be sensitive to frequency, word-level associations, and discourse factors. The findings for N400 effects with thematic role violations are mixed: While the contrast of animate compared to inanimate objects has also been reported to cause an N400 (see below), numerous studies report a surprising absence of an N400 for outright violations of animacy restrictions (see Kuperberg 2007; Paczynski and Kuperberg 2009; Paczynski and Kuperberg 2011). These findings, collectively referred to as semantic illusions, have led to the suggestion that the N400 indicates the relative ease of retrieving a word from memory, given the current context (Brouwer et al. 2012). The role of the N400 in the processing of lexical case marking is outlined in more detail below.

Frisch and Schlesewsky conclude that the enhanced P600 reflects the additional processing costs caused by the violation of German case marking patterns in all conditions, while the enhanced N400 reflects the additional processing cost caused by the lack of an animacy contrast between the participants.

2 Example stimuli given by Frisch and Schlesewsky (2001):

1. (animate, correct) Paul fragt sich, welchen Angler der Jäger gelobt hat. Paul asks himself [which angler] ACC [the hunter] NOM praised has.

2. (animate, incorrect) Paul fragt sich, welcher Angler der Jäger gelobt hat. Paul asks himself [which angler] NOM [the hunter] NOM praised has.

3. (inanimate, correct) Paul fragt sich, welchen Förster der Zweig gestreift hat. Paul asks himself [which forester] ACC [the twig] NOM touched has.

4. (inanimate, incorrect) Paul fragt sich, welcher Förster der Zweig gestreift hat. Paul asks himself [which forester] NOM [the twig] NOM touched has. 
Recent evidence suggests that also for English sentences, object animacy may play a role in the processing of comparatively easy, grammatical sentences. Paczynski and Kuperberg (2011) report EEG evidence on the comprehension of English main clauses with animate or inanimate objects that either matched or violated the semantic selectional restrictions of the verb. In Experiment 1, the authors find larger N400 amplitudes at centro-posterior sites for animate than for inanimate postverbal objects in sentences without any violations ("At headquarters the manager interviewed the applicant for thirty minutes" vs. "At headquarters the manager perused the application for thirty minutes"; Paczynski and Kuperberg 2011: 14-15).

Production studies (Ferreira 1994; van Nice and Dietrich 2003) also support the notion that argument animacy and grammatical and thematic role assignment interact, by showing that speakers have a tendency to produce more complex sentences in order to make the animate argument the grammatical subject. For English sentence production prompted by noun-noun-verb presentation, Ferreira (1994) reported an animacy effect for theme-experiencer verbs (with more passivizations occuring with inanimate than with animate themes), while agent-patient verbs did not show animacy effects and hardly ever were uttered in passive sentences. For German sentence production however, animacy also seems to influence production of sentences with action verbs. Van Nice and Dietrich (2003) investigated the role of animacy for word order in a series of picture description tasks, using action verbs describing agent-patient scenarios, and both animate and inanimate agents and patients. They found that animates are generally produced in early sentence positions. The joint influence of an argument's animacy and thematic role seems to be task dependent: In all tasks, there was a tendency for animates to be uttered in early positions, and animate patients lead to more passives than inanimate patients. Importantly, for a speaking-from-memory task, there was no effect of patient animacy when the agent was animate. However, scenarios with inanimate agents evoked more passives than those with animate agents, especially so if the patient was animate. The authors argue that this interaction does not reflect the influence of verb type on animacy processing (since all verbs were agent-patient verbs), but of thematic role, and reflects an interplay between "animate first" and "agent first" principles in the production of German sentences.

The findings reported by van Nice and Dietrich (2003) fit well with earlier findings reported by Prat-Sala and Branigan (2000), suggesting that the arguments' animacy interacts with other factors (like saliency in the current context) during sentence production. The authors prompted sentence production in English and Spanish using a picture description task with a short context story for each picture. They found that the assignment of grammatical roles is 
influenced by the arguments' conceptual accessibility, ${ }^{3}$ which is the result of an interplay between the arguments' inherent accessibility (based on unalterable semantic properties like animacy) and derived accessibility (based on the saliency of the argument in the context). Although animate arguments are usually realized as subject because of their high inherent accessibility, the context can override this preference and lead to different grammatical role assignment.

Because of findings like the ones described above, contrasts in argument animacy play an important part in grammatical and thematic role assignment in models of sentence comprehension. In Kuperberg's account (Kuperberg 2007), two processing streams work in parallel. The first is a combinatorial processing stream, consisting of two streams calculating morphosyntactic and lexical-thematic relationships (the latter of which use argument animacy information). The second processing stream calculates the lexical-semantic relationships between the words in the sentence, probably accessing their mental lexicon entries. In the extended Argument Dependency Model (Bornkessel-Schlesewsky and Schlesewsky 2006), animacy information and case marking contribute to calculate the prominence of each argument during the second phase of processing nonpredicating elements. This prominence information is later used in building the representation of the whole sentence. The different kinds of information used in parsing (like word order, case marking, or animacy) can be assigned different weights to reflect their importance in processing sentences of a specific language. Both models account for the fact that a sentence lacking both kinds of information (i.e., morphosyntactic and animacy contrast) leads to increased processing cost. This matches the observation that without a contrast in animacy, both arguments could take the grammatical role of subject in active sentences (at least, for the majority of verbs). Both models also reflect the fact that although animacy is a semantic property, it appears that it is used not only in strictly semantic processing, but also in the processing of some more general kind of animacy contrast pattern.

\subsection{Different kinds of verbs: Effects of noncanonical case marking}

The deviations described so far depend on unalterable semantic properties of the arguments, namely, the animacy of the participants in the event. However,

\footnotetext{
3 Bock and Warren (1985: 50): "Conceptual accessibility is the ease with which the mental representation of some potential referent can be activated in or retrieved from memory. We assume that conceptual accessibility is closely tied to characteristics of perceptual and conceptual representation, with accessible concepts being those that are in some sense most "thinkable"- those whose mental representations are learned earliest and are most richly detailed in adult representations of knowledge."
} 
situations can also deviate from prototypical transitivity because of the semantic properties that the participants have in the specific situation, that is, the semantic properties assigned by a verb to its arguments. Experiencer verbs like to please and to frighten do not describe true agent-patient-scenarios, and assign different semantic properties to their arguments than verbs describing prototypically transitive situations. Some of these nonprototypically transitive verbs also show non-standard syntactic behavior (see, for example, Belletti and Rizzi 1988), signaling their deviation from prototypically transitive semantics. According to the Argument Selection Principle (Dowty 1991), the distribution of semantic properties to the arguments of a verb influences the syntactic realization of a verb. This means that the argument bearing most semantic properties of a typical agent (like causing a change of state in another participant) will be realized as the syntactic subject and the argument bearing fewer of these properties will be realized as the syntactic object. Situations in which neither participant is sufficiently "more proto-agent-like" than the other can lead to verb pairs with very subtle differences in meaning (as in like vs. please), but opposite argument linking patterns (often subject- vs. object-experiencer verbs) (Wechsler 1995). Argument selection in Dowty's account depends on one argument bearing more semantic properties of the agent proto-role than the other. The semantic properties contributing to the agent proto-role do not include animacy. Still, animacy is strongly implied in some of the properties contributing to the proto-agent role, like sentience or perception, and hence plays an indirect role.

Another syntactic symptom of a verb not being prototypically transitive (or "less transitive", Blume 2000) is non-standard case marking in case marking languages like German. The four cases of German (nominative, genitive, dative and accusative) are morphologically marked on determiners, nouns and adjectives preceding nouns, but are not always morphologically visible due to widespread case syncretism. ${ }^{4}$ The standard case marking pattern for most German two-place verbs is nominative case for grammatical subjects and accusative case for grammatical objects. ${ }^{5}$ A small class of German two-place verbs, however, assign nominative-dative instead of nominative-accusative to their arguments. German dative-assigning verbs can have different unmarked word orders, some with DAT-NOM orders resembling stimulus-experiencer verbs (e.g., gefallen in Mir gefällt der Film, me.DAT pleases the.NOM movie(.NOM); 'The movie pleases me'),

\footnotetext{
4 see Bayer et al. (2001); for the interplay between animacy, case syncretism and grammatical gender in German, see Krifka (2009).

5 Other classes of transitive verbs assign various propositional objects, and there is a small and dwindling class of verbs that assign genitive case.
} 
some of them with unmarked NOM-DAT word orders that are usually called "active dative verbs" in the psycholinguistic literature (e.g., folgen in Peter folgt dem Auto 'Peter.(NOM) follows the.DAT car.(DAT)').

Crosslinguistically, the class of noncanonical case marking verbs tends to include verbs with similar meanings in different case marking languages, irrespective of the specific case marking system (Blume 2000). They differ from prototypically transitive verbs not only in their case marking pattern, but also in the distribution of semantic properties to the arguments. Therefore, a German verb assigning nominative-dative case to its arguments is guaranteed to have non-prototypically transitive semantics (Blume 2000), with a dative object that is more agentive than that of a prototypically transitive nominative-accusative assigning verb (Meinunger 2007; see also Grimm 2010).

Both the semantics and the syntax of German dative-assigning verbs differ from prototypically transitive accusative-assigning verbs (see Bayer et al. 2001; Fanselow 2000; Woolford 2006; McFadden 2004; Meinunger 2006; for different analyses). In this study, we will limit ourselves to the generalization that dative objects of twoplace verbs have a different syntactic position than accusative objects, and that encountering a nominative-dative assigning verb leads to increased syntactic processing cost compared to a nominative-accusative assigning verb (Hopf et al. 1998; Bader et al. 2000; Bayer et al. 2001). In line with previous psycholinguistic evidence, we will also distinguish between dative-assigning verbs with underlying NOM-DAT and DAT-NOM word orders (Bornkessel et al. 2004).

Dative-assigning verbs are also processed differently from accusative-assigning verbs. In sentences with active dative verbs, the assignment of dative instead of accusative case during the reanalysis of temporally ambiguous grammatical German sentences leads to stronger garden path effects (Bader et al. 2000) and differences in ERPs (Hopf et al. 1998). Bornkessel et al. (2004) find different effects of word order variations on sentences with dative-assigning instead of accusative-assigning verbs, with object-initial sentences producing an enhanced P600 component in the accusative condition, but an N400 in the dative condition. The processing differences between accusative and dative verbs are explained with the assumption that an additional layer of projection needs to be established to assign lexical instead of structural case. This layer is termed KP for Kase Phrase; its insertion is thought to not be as syntactically costly as more fundamental phrase structure revisions, which also is the explanation for the absence of a P600 with dative-assigning verbs. This establishment of the KP is thought to be followed by lexical reaccess to the lexical entry of the object to check if lexical case is morphologically licensed (a process supposed not to be necessary for structurally case marked accusative objects, and thought to explain the unexpected N400 instead of a P600 upon encountering a dative-assigning verb; 
see Bader et al. 2000; Bayer et al. 2001; Hopf et al. 1998). Another, less syntactically explicit explanation is that dative verbs activate more flexible word order patterns than accusative verbs, irrespective of the specific verb's unmarked word order (Bornkessel et al. 2004). In the extended Argument Dependency Model (Bornkessel-Schlesewsky and Schlesewsky 2006: 792), the special semantic and syntactic properties of dative-marked arguments are discussed. The model predicts different processing behavior for constructions including a dative than for those including only canonical (i.e., structural) cases like nominative and accusative.

To sum up the preceding introduction, non-prototypically transitive sentences can deviate from prototypical transitivity because of the inherent semantic properties of the verb's arguments (like animacy), but also because of the semantic properties that the arguments have in the specific situation described by the verb (like causing a change of state in another participant).

Both kinds of deviation from prototypical transitivity have been shown to affect the comprehension and production of sentences in various languages. However, it is still unknown if and how the effect of object animacy is modulated by verb type. Is the reaction to one deviation, namely the presence of two animate arguments, affected by the reaction to another deviation, namely noncanonical case marking? According to the literature, the subjects of a dativeassigning verb are less agentive, and the objects likely to be more agentive than those of accusative-assigning verbs. Will the increased workload of processing two animate arguments and the non-prototypically transitive semantics and noncanonical case marking pattern of the verb simply add up? Or will it be easier to process animate objects with noncanonical verbs, because they fit the higher agentivity of the object?

Our hypothesis is that the object animacy effect (i.e., the additional processing cost caused by two animate arguments in the absence of morphosyntactic role-assigning information) is modulated by verb class. In the following, we present an ERP study investigating the interaction between object animacy and verb class on the processing of transitive German sentences.

\section{Material and methods}

\subsection{Language material}

Language material consisted of 128 sentences, with 32 items in four different conditions, pairing either accusative- or dative-assigning verbs with either inanimate or animate objects. All critical sentences were grammatical, verb- 
final embedded sentences with SOV word order. Arguments were bare plural NPs. The NPs chosen do not carry overt morphological case marking in their plural forms, so neither case marking nor number congruency on the verb allowed grammatical role assignment. Dative-assigning verbs were selected from a list of German dative-assigning verbs (Meinunger 2007), chosing only verbs with standard linking patterns like folgen, 'to follow' (no object experiencer verbs like gefallen, 'to please'), that semantically allowed inanimate and animate objects. In the following, we will refer to the two conditions with accusative- or dative-assigning verbs as two verb classes (accusative or dative) for brevity's sake. An adverb was inserted between the object NP and the critical verb to allow some time for the processing of object animacy before the verb class became available. We constructed 32 critical sentence quartets using 25 animate subject NPs, 26 inanimate and 27 animate object NPs and 32 verb pairs. Two accusative-assigning verbs (ablehnen 'to reject', and mögen 'to like'), were used in two verb pairs, all other verbs occurred only once. An example of a typical sentence quartet is given in Example 1. The complete list of critical sentences used in our experiment is given in the Appendix. Animate and inanimate object NPs were controlled for length $(t(51)=0.62, p>0.5)$ and frequency $(t(49)=0.60, p>0.5$; frequencies unavailable for two objects) according to the dlexDB corpus (Heister et al. 2011). Accusative- and dativeassigning verbs were also controlled for length $(t(62)=-1.4, p>0.1)$ and frequency $(t(61)=1.3, p>0.1$, frequency unavailable for one verb) according to the dlexDB corpus.

The final list consisted of 192 sentences and contained 128 critical sentences (32 per condition) interspersed with 64 filler sentences. Representative examples of filler sentences are Um Konserven zu öffnen, benutzt Maria einen Dosenöffner oder ein Taschenmesser 'To open cans, Maria uses a can opener or a pocket knife.' or Dass Nilpferde Krokodile töten, begeistert den Regisseur, aber nicht den Tierarzt '[The fact] that hippopotamuses kill crocodiles delights the director but not the vet.' Filler sentences were presented to avoid syntactic priming (Frazier et al. 1984; Bock 1986; Branigan et al. 2000; Ledoux et al. 2007) and to prevent probands from developing reading strategies.

Before the EEG experiment, sentences were rated for acceptability in an online study by 351 German native speakers (mean age was 25.1 years, 124 probands were male) using a 6-point scale with 1 the best and 6 the worst rating. This rating scale corresponds to the grade system in German schools, which can be assumed to be familiar to all native speakers. Importantly, a rating of five or six implies that a sentence "does not pass", whereas any better judgment means that the sentence is acceptable. Sentences with animate objects were rated worse than sentences with inanimate objects 
(inanimate-accusative $=3.6, \mathrm{SD}=0.2$, animate-accusative $=3.8, \mathrm{SD}=0.2$; inanimate-dative $=3.7, \mathrm{SD}=0.2$; animate-dative $=3.8 ; \mathrm{SD}=0.2$ ). This main effect of object animacy was small but statistically significant $(F(1,31)=9.6, p<0.01$, two-way ANOVA of means over items). There was no significant effect of verbal case marking pattern and no interaction between verb class and object animacy. The mediocre ratings of the sentences fit our own intuition, suggesting that the sentences may sound a little odd, but are grammatical and comprehensible. For presentation during the ERP measurement, three different lists were constructed by pseudorandomizing the 192 sentences to avoid order effects. 14 questions were asked after critical sentences and twelve questions were asked after filler sentences. Half of the questions had the correct answer 'yes', the other half had the correct answer 'no'. The questions did not systematically target subject-object resolution or resolution of case marking patterns to avoid directing the probands' attention to these factors. Probands immediately received written feedback to the answers they gave.

(1) Example of a typical sentence quartet. Note that case morphology is not marked overtly on the arguments.)

(a) inanimate object, accusative-assigning verb:

Tim glaubt, dass Tauben Luftballons gerne mögen,

Tim believes that dove.PL.(NOM) airballoon.PL.(ACC) ADV like.3PL

und Tom glaubt das auch.

and Tom believes that too.

'Tim believes that doves rather like balloons, and Tom believes that, too.'

(b) animate object, accusative-assigning verb:

Tim glaubt, dass Tauben Krähen gerne mögen, und...

Tim believes that dove.PL.(NOM) crow.PL.(ACC) ADV like.3PL and ...

'Tim believes that doves rather like crows, and ....'

(c) inanimate object, dative-assigning verb:

Tim glaubt, dass Tauben Luftballons gerne folgen,

Tim believes that dove.PL.(NOM) airballoon.PL.(DAT) ADV follow.3PL und...

and ...

'Tim believes that doves like following balloons, and ....'

(d) animate object, dative-assigning verb:

Tim glaubt, dass Tauben Krähen gerne folgen,

Tim believes that dove.PL.(NOM) crow.PL.(DAT) ADV follow.3PL

und...

and ...

'Tim believes that doves like following balloons, and ....' 


\subsection{Methods}

\subsubsection{Probands}

Twenty-four probands were recruited via the Humboldt University's experimental proband recruitment service (PESA). All probands were right-handed, spoke German as their only native language and reported no known reading or language-related problems. All probands gave written and informed consent. The data of four probands were excluded from the data analysis because of too many movement artifacts, leading to average values calculated from fewer than 20 ERP segments in these probands. The mean age of the remaining 20 probands (four males) was 25.3 years $(\mathrm{SD}=4.0$ years). Probands received 25 Euros compensation.

\subsubsection{Procedure}

Probands were seated in a comfortable chair in front of a computer screen, with an average distance of about $80 \mathrm{~cm}$, in an electrically shielded EEG recording chamber. They were instructed to rest their hands on two response button boxes. Half of the probands were assigned the left button for answering 'no' and the right for answering 'yes'. For the other half, the assignment was reversed. The experiment consisted of an instruction phase and the experimental phase. Probands were first instructed orally and then again in written form on the screen during the instruction phase. Words were presented visually in the center of a computer screen using the Presentation software by Neurobehavioral Systems Inc. (version 16.1). Before the first word of each sentence, a blank screen was presented for $1200 \mathrm{~ms}$, followed by an asterisk presented in the center of the screen for $500 \mathrm{~ms}$. The first two and last three words of the matrix sentence were presented together, while the remaining words were presented in a word-by-word fashion. This means that the embedded sentence and the first two postverbal words (und and a personal name) were presented as single words:

\section{Tim glaubt,| dass | Tauben | Luftballons | gerne | mögen, | und | Tom | glaubt das auch.}

Each word or string of words was presented for $700 \mathrm{~ms}$, followed by a $100 \mathrm{~ms}$ blank screen. Probands pressed one of the response buttons to change to the next screen during the instruction phase and to start the presentation of the next sentence during the experiment. They answered the questions by pressing 
the left or right response button, respectively. Feedback on the answers to the questions was presented for 1500 ms. About every 30 sentences, probands were offered to take a short break, resulting in 6 breaks during the course of the experiment. Before the actual experiment, probands saw three practice trials. The experimental phase lasted about $45 \mathrm{~min}$.

The EEG was recorded with $32 \mathrm{Ag} / \mathrm{AgCl}$ sintered ring electrodes attached to an elastic cap (EasyCap, Gilching) and connected to an Easy-Cap Electrode Input Box EiB32. Electrodes were placed in the following positions according to the 10-20 system: C3, C4, CP5, CP6, CPz, Cz, F3, F4, F7, F8, FC5, FC6, FCz, Fz, 01, 02, Oz, P3, P4, P7, P8, POz, Pz. The EEG signal was amplified with a BrainAmp DC amplifier (Brain Products, Gilching) connected to a personal computer outside of the EEG chamber via a USB2 Adapter (Brain Products, Gilching). The signal was recorded with a digitization rate of $250 \mathrm{~Hz}$. Eye movements were monitored by recording the ectrooculogram. Horizontal movements were recorded from the left and right outer canthi, and vertical movements were recorded above and below the right eye. Electrodes were referenced to linked mastoids. Electrode impedances were kept below $5 \mathrm{kOhm}$. Data were processed using the Brain Vision Analyzer software (Brain Products, Gilching).

Before segmentation, the raw data were filtered with two Butterworth Zero Phase Filters, one $0.5 \mathrm{~Hz}$ low-cutoff/high-pass filter and one $70 \mathrm{~Hz}$ high-cutoff/ low-pass filter, and a $50 \mathrm{~Hz}$ Notch filter. The filtered data were segmented into time windows from $100 \mathrm{~ms}$ before to $900 \mathrm{~ms}$ after onset of the critical words (i.e., onset of the subject, object, adverb, verb, and of the postverbal und), resulting in different segments timelocked to the indicated word positions in the sentence. After segmentation, a baseline correction was performed from $100 \mathrm{~ms}$ before stimulus onset to stimulus onset. Trials including artifacts or blinks were rejected semi-automatically from the segmented data. Artifacts were defined according to the following parameters: The maximal allowed voltage step per sampling point was $50 \mu \mathrm{V}$. The maximal allowed absolute difference of two values in a segment was $300 \mu \mathrm{V}$. The minimal allowed amplitude was $-200 \mu \mathrm{V}$, the maximal allowed amplitude was $200 \mu \mathrm{V}$. The lowest allowed activity ( $\max -\min$ ) was $0.5 \mu \mathrm{V}$ in an interval of $100 \mathrm{~ms}$. Averages were calculated per condition per proband. Probands with fewer than 20 trials per condition were excluded from the statistical data analysis and Grand Averages, leaving 20 probands of the original 24. For the remaining 20 probands, $14 \%$ of the original data were rejected $(\mathrm{SD}=7.5 \%)$. Grand Averages were smoothed with an additional $10 \mathrm{~Hz}$ low-pass filter for data presentation. 


\subsubsection{Data analysis}

We defined the following regions of interest (ROIs): left frontal (F3, F7, FC5), right frontal (F4, F8, FC6), left posterior (P3, P7, CP5) and right posterior (P4, $\mathrm{P} 8, \mathrm{CP} 6)$. These regions of interest were chosen based on visual data inspection and previous studies (Bornkessel et al. 2004 report an interaction between different dative verb classes and word order in left-posterior and left-anterior ROIs in their Exp.2). Mean voltages for the single ROIs were calculated from the averages of all probands. Time windows were chosen based on visual inspection of the data and comparisons with previous studies. The specific time windows analyzed for each word position are specified in the results. For each chosen time window, we performed a repeated measures ANOVA of the mean voltages in each of the five ROIs, with within-subject factors ROI and ANIMACY (object animacy) for objects and adverbs, and ROI, ANIMACY and CASE (verb class) for the verbs (the first point in time when verb class information became available). GreenhouseGeisser corrections were applied when the degrees of freedom in the numerator were higher than 1. Based on our initial hypothesis, we compared the effects of ANIMACY for the two preverbal words, and the interaction of ANIMACY and CASE for the verbs. Based on the results of previous experiments using comparable stimuli, but different experimental techniques (eyetracking and self-paced reading; Czypionka 2014: Ch.3-4), we expected the interaction of the within-subject factors ANIMACY and CASE to be present but rather small, especially in relation to the main effect of ANIMACY.

Analyses inside the single ROIs were performed in a hierarchical fashion (i.e., only statistically significant interactions of ANIMACY and CASE in the respective ROIs were pursued).

\section{Results}

\subsection{Answer accuracy}

For the probands included in the study, the mean answer accuracy was 24.8 $(\mathrm{SD}=1.1)$ correctly answered questions for a total number of 26 questions. The lowest number of correctly answered questions was 22, the highest number of correctly answered questions was 26. Answer accuracies were not used for data rejection, given the generally good performance of the probands in the task. 


\subsection{ERP results}

Results are described for the ERPs timelocked to the indicated word positions in the sentence. Only statistically significant effects are reported.

\subsubsection{Object}

Grand average ERPs are shown in Figure 1. In the time window from 400 to $600 \mathrm{~ms}$, there was a statistically significant main effect of ROI $(F(3,57)=11.38$, $p<0.001)$ and a statistically significant interaction of ROI and ANIMACY $(F(3,57)=5.47, p<0.05)$. The main effect of object animacy was statistically significant in the right-posterior and right-anterior ROIs (right posterior: $t(19)=$ 2.54, $p<0.05$, right-anterior: $t(19)=3.0, p<0.01$ ). Waveforms were more negative-going for animate than for inanimate objects at right-anterior and rightposterior sites, starting shortly after $400 \mathrm{~ms}$.

Object

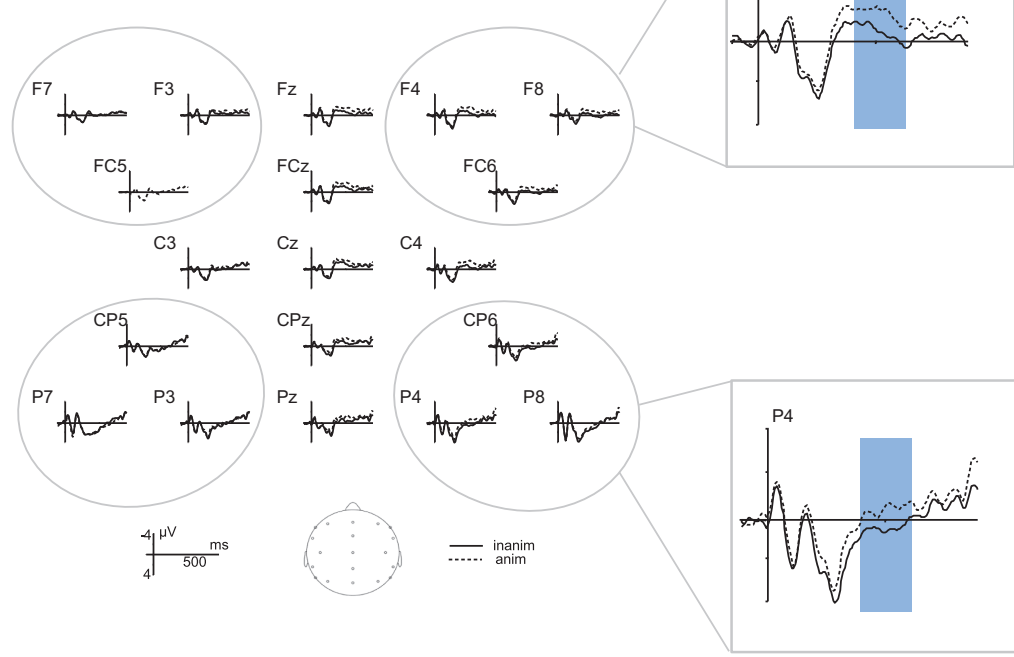

Figure 1: Experiment 2, Grand average ERPs at selected electrodes time-locked to the object NPs, with inanimate vs. animate object NPs. Grand average ERPs are given for selected ROIs with marked time windows for statistically significant effects. Negativity is plotted upwards. 


\subsubsection{Adverb}

Grand average ERPs are shown in Figure 2. In the time window from 300 to $500 \mathrm{~ms}$, there was a statistically significant main effect of ROI $(F(3,57)=11.03$, $\mathrm{p}<0.001)$, and a statistically significant interaction of ROI and ANIMACY $(F(3,57)=4.24, \mathrm{p}<0.05)$. There was a main effect of ANIMACY in the left-posterior ROI $(t(19)=2.58, p<0.05)$ and the right-posterior ROI $(t(19)=2.93, p<0.01)$. Waveforms for the adverbs were slightly more negative-going in the animate than in the inanimate conditions between 300 and $500 \mathrm{~ms}$.

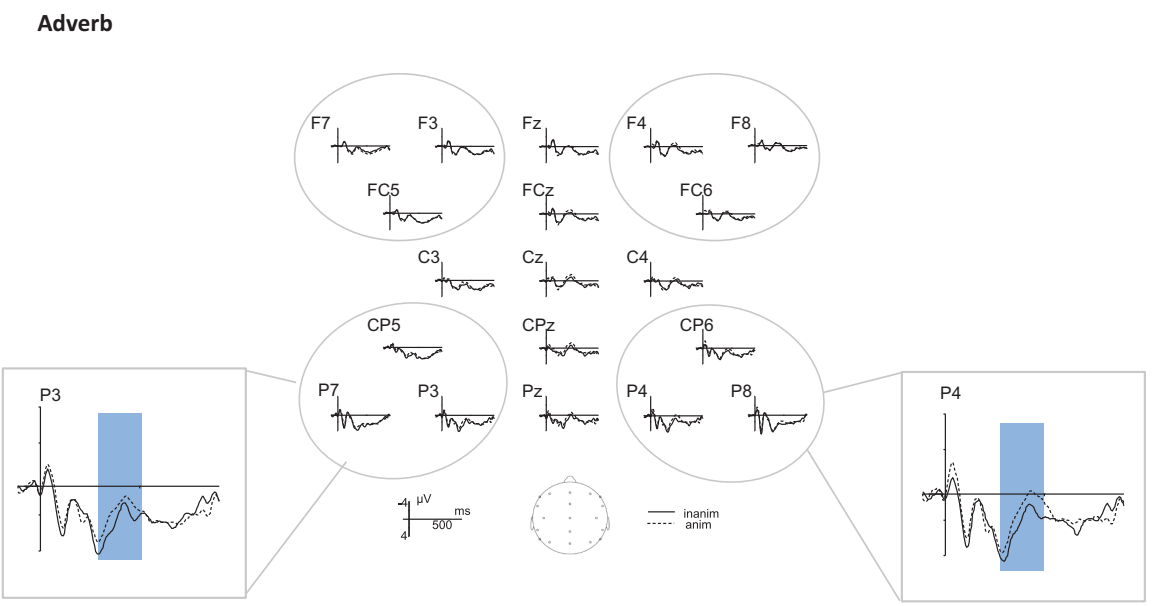

Figure 2: Experiment 2, Grand average ERPs at selected electrodes time-locked to the adverb, showing inanimate vs. animate conditions. Grand average ERPs are given for selected ROls with marked time windows for statistically significant effects. Negativity is plotted upwards.

\subsubsection{Verb}

Grand average ERPs are shown for accusative conditions in Figure 3, panel A, and for dative conditions in Figure 3, panel B. (Here, stimuli were different for the first time for dative and accusative conditions, and thus, we included the variable CASE in the analysis.) In the time window from 200-600 ms, there was a statistically significant main effect of ROI $(F(3,57)=23.80, p<0.001)$ and a statistically significant interaction of ROI and ANIMACY $(F(3,57)=3.96$, $p<0.05)$. Planned comparisons in the ROIs revealed a statistically significant interaction of ANIMACY and CASE $(F(1,19)=5.73, p<0.05)$ in the left-posterior ROI. The main effect of ANIMACY in the left-posterior ROI was statistically significant for accusative conditions $(t(19)=-2.41, p<0.05)$, but not for dative 


\section{Verb}

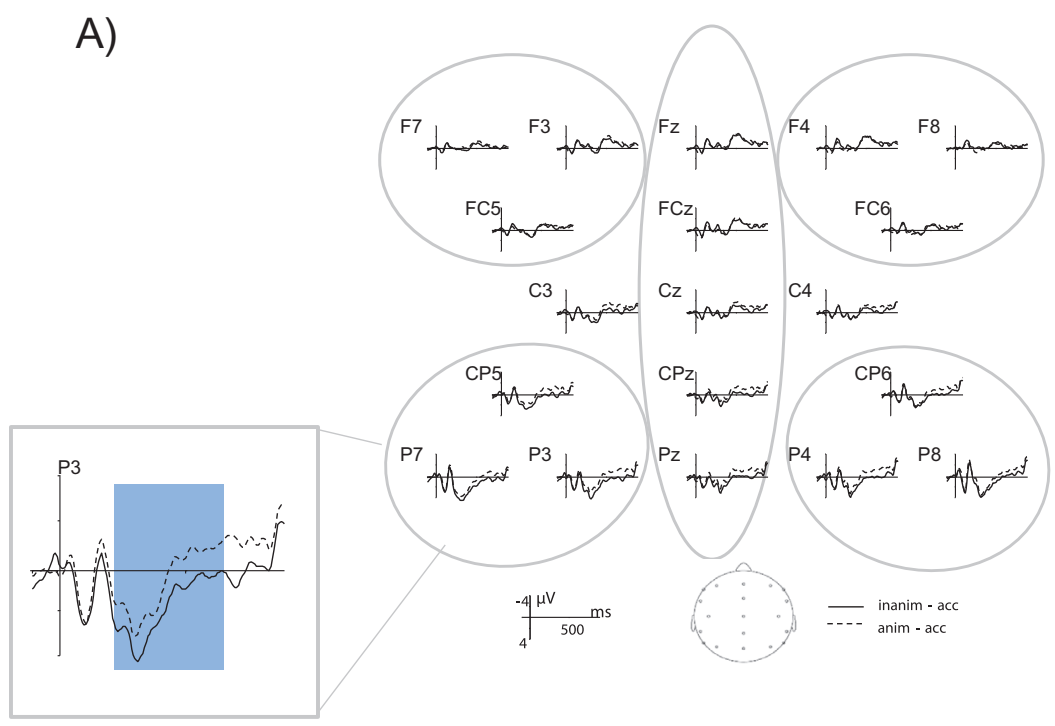

B)

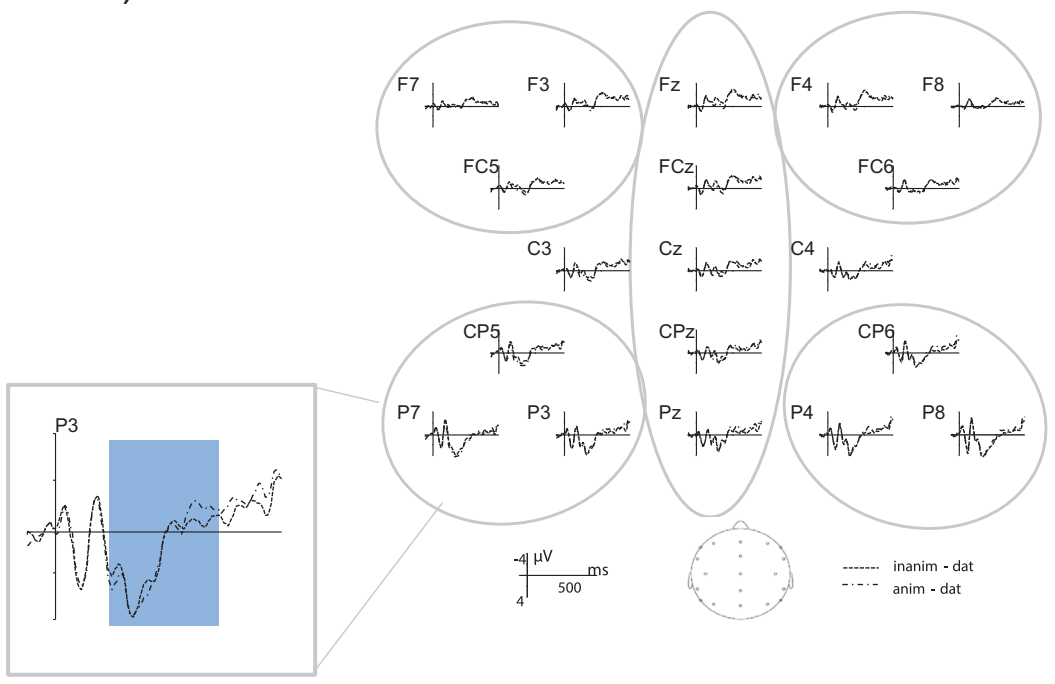

Figure 3: Experiment 2, Grand average ERPs at selected electrodes time-locked to the verb for (A) accusative conditions, showing inanimate-accusative vs. animate-accusative, and (B) dative conditions, showing inanimate-dative vs. animate-dative conditions. Grand average ERPs are given for selected ROls with marked time windows for statistically significant effects. Negativity is plotted upwards. 
conditions $(t(19)=0.9, p>0.3)$. The main effect of CASE in the left-posterior ROI was statistically significant for inanimate conditions $(t(19)=2.90, p<0.01)$, but not for animate conditions $(t(19)=-0.97, p>0.3)$. In the left-posterior ROI, waveforms for the animate-accusative condition showed a broad negative shift relative to the inanimate-accusative condition, starting at around $200 \mathrm{~ms}$ and continuing until the end of the segment. Waveforms for inanimate-dative and animate-dative conditions remained closely together.

\section{Discussion}

\subsection{Main effects of object animacy}

Main effects of object animacy were visible on the object NPs and adverbs. In addition, there were main effects of object animacy on verbs in the accusative conditions. Waveforms were shifted to more negative values for animate compared to inanimate conditions from 200 to $400 \mathrm{~ms}$ onward, with one interesting exception (see the paragraph below on interactions). We interpret these negative shifts as representing the additional processing cost caused by two animate arguments (instead of animate-inanimate sequences) without morphological case marking. The direction of the main effects of object animacy fits the results reported by Frisch and Schlesewsky (2001), with animate objects causing negativities compared to inanimate objects. Frisch and Schlesewsky (2001) presented transitive German sentences with two nominative-marked arguments (making the sentences ungrammatical), the second of which was either animate or inanimate. Compared to a grammatical baseline condition, they found enhanced P600 components for both ungrammatical conditions. If both arguments were animate, they additionally found an enhanced N400 component, which they interpret as representing problems of thematic hierarchizing. The main effects of object animacy found on the object and adverb also fit the findings reported by Paczynski and Kuperberg (2011) for the grammatical conditions in Experiment 1 ("At headquarters the manager interviewed the applicant for thirty minutes" vs. "At headquarters the manager perused the application for thirty minutes"; Paczynski and Kuperberg 2011: 14-15). For this study, the authors report an enhanced N400 amplitude for animate compared to inanimate objects at centroposterior sites. (Importantly, these findings cannot be compared too directly to our own; the verbs in the cited study had semantic selectional restrictions for either animate or inanimate objects, and the objects were postverbal.) 
The negative shift in our data starting after the onset of the accusative verb looks different from the classical N400 (Kutas and Hillyard 1980; Kutas and Hillyard 1982): It is distributed over left posterior sites rather than centroposterior sites, and it is a broad negative shift rather than a negative peak (as in, for example, Frisch and Schlesewsky 2001) with a clear beginning and end. Still, we assume that it is also caused by the extra workload for processing semantic or thematic information (i.e., they represent the additional workload of processing nonstandard animate-animate sequences instead of the standard animate-inanimate sequences).

Difficulties in thematic hierarchizing appear to be something different than outright violations of a verb's selectional restrictions concerning argument animacy. Kuperberg et al. (2007) found an enhanced P600, not N400, on the verbs of English transitive sentences with inanimate subjects. Unlike our stimuli or the stimuli used by Frisch and Schlesewsky (2001), Kuperberg et al.'s stimuli contained clear violations of the verbs' selectional restrictions for subject animacy. They found that combining an inanimate subject with a verb selecting for an animate subject led to a P600 compared to a non-violated baseline condition (baseline condition: For breakfast the boys would eat toast and jam). This held regardless of whether the inanimate subject was semantically related to the verb (as in For breakfast the eggs would eat toast and jam) or whether the inanimate subject was not semantically related to the verb (For breakfast the eggs would plant flowers in the garden). Their findings add to previous work on semantic illusions (e.g., Kuperberg et al. 2003; Kuperberg et al. 2006; Kim and Osterhout 2005; Hoeks et al. 2004), finding no N400 for violations of animacy restrictions. They conclude that the P600, but not the $\mathrm{N} 400$ is a part of the reaction to animacy restriction violations. In contrast, they find an N400 in sentences with a violation of pragmatic expectations (For breakfast the boys would plant flowers in the garden). One of the explanations they suggest for the absence of an N400 in sentences with animacy violations is that the process reflected by an enhanced N400 (i.e., semantic integration) might be attenuated because of another process reflected by the P600 (namely, the processing of thematic role violations, see Kuperberg et al. 2007: 234-235; see; Sassenhagen et al. 2014 for a recent support of the P600 as a domaingeneral P3 response indexing task relevance and processing time instead of structural or combinatorial processing per se). Our stimuli did not contain violations of semantic restrictions or syntactic structure nor bore specific task-relevance, and did not elicit enhanced P600 components; this pattern fits the findings described in the literature. It also fits the findings reported by Paczynski and Kuperberg (2011) for the grammatical conditions in their first experiment (see the above paragraph). 


\section{2 (No) main effects of verb class}

On the verb position, there is no statistically significant main effect of verb class. However, the descriptive difference between the verb classes at this position fits findings in the literature associating German dative-assigning verbs with more negative-going waveforms than accusative-assigning verbs. Hopf et al. (1998) investigated the processing of dative-assigning compared to accusative-assigning verbs. They found a broad negative shift for dative compared to accusative verbs, on centroposterior sites, starting around $300 \mathrm{~ms}$ after the presentation of the critical verbs. They interpret this negativity as reflecting additional processing costs caused by the assignment of lexical dative instead of structural accusative case to the object NP. They assume that upon encountering the dative-assigning verb, the parser has to reaccess the lexical entry of the object NP to check whether dative case is morphologically licensed, and suggest that the processing difficulty is lexical rather than syntactic. The results of this study seem to fit with ours, given that Hopf et al. report negative shifts for dative compared to accusative verbs when case was not overtly marked. However, the stimulus material of Hopf et al. contained two animate arguments in complex, but grammatical German sentences. In our experiment, the negative shift occurred relative to the inanimate-accusative condition. The waveforms for both animate conditions did not differ between the accusative and dative conditions. Thus, while we also find a negative shift for the processing of dative compared to accusative-assigning verbs, the stimulus material in both studies seems to differ in too many ways for a one-on-one transfer of explanations. Bornkessel et al. (2004) also found negativities associated with dative-assigning verbs. They found that argument order manipulations elicit P600 effects for accusative-assigning verbs, while they elicit enhanced N400 components for dative-assigning verbs. They argue that word order manipulations cause a revision of phrase structure with accusative-assigning verbs, while dativeassigning verbs make access to object-initial word orders easier, irrespective of the specific verb's preferred word order (subject-first or object-first). In a second experiment, they manipulated the argument order for active dative verbs (like folgen, 'to follow') and object-experiencer dative verbs (like gefallen, 'to please'). They found interactions between word order and verb class in the 350 to $550 \mathrm{~ms}$ time window on left-hemispheral ROIs, while they found main effects of order in central-posterior and right-posterior ROIs. They argue that while the P600 reflects the reanalysis of phrase structure, the N400 found in their experiments reflects the revision of case marking. This explanation of their results could also be applied to our study, since we find negativities in the inanimate conditions once it has become clear that the verb assigns dative instead of accusative case. 
Therefore, we believe that any potential main effect of verb class surfaces as an interaction of verb class and object animacy in our study.

\subsection{Interactions between object animacy and verb class}

There was an interaction of object animacy and verb class in the time window from 200 to $600 \mathrm{~ms}$ after the presentation of the verb in the left-posterior ROI, showing that the effect of object animacy was modulated by verb class. Waveforms for the animate-accusative condition were more negative-going than in the inanimate-accusative condition (see Figure 3, panel A), while waveforms for both dative conditions did not differ from each other or the animateaccusative condition (see Figure 3, panel B). That is, object animacy caused a broad negative shift from $200 \mathrm{~ms}$ onwards for accusative-assigning verbs. This broad negative shift of animate relative to inanimate conditions was not visible for dative-assigning verbs (both inanimate-dative and animate-dative followed the waveform of the animate-accusative condition). Crucially, in the dative condition, object animacy did not cause a difference in the waveforms. The difference between the accusative and dative condition in their processing of object animacy fits our initial hypothesis: In sentences with accusative-assigning verbs, animate objects cause higher processing costs than inanimate objects. In sentences with dative-assigning verbs, the difference between the processing costs for inanimate and animate objects is less pronounced or even absent. We interpret the negativity found in the animate-accusative condition as a reflection of thematic processing difficulty. The negativity found in the dative condition, irrespective of object animacy, might reflect reassignment of case that is necessary for both animate and inanimate objects. Importantly, this does not tell us if object animacy is used at all in the processes reflected in the dative condition (as it is for the accusative condition). One might argue that dative-assigning verbs do not only enable access to different word orders (as assumed by Bornkessel et al. 2004), but also license argument animacy patterns that diverge from the animate subject - inanimate object sequence preferred by accusative verbs.

The stimuli we presented were grammatical German sentences, not putting a special strain on the working memory and not meant to elicit strong garden paths. This might explain the subtlety of the interaction effects in the betweenROI comparisons. In spite of the sentences being grammatical, the influence of animacy was strong enough for statistically significant results. The results of our experiment support our hypothesis, showing an interaction between object animacy and verb class during sentence comprehension. However, the results do not explain which linguistic processes are reflected in this interaction. 
In the following, we propose different linguistic processes that could explain the interplay between object animacy and verb class. We assume that one, or several, of the processes proposed here do at least contribute to the interaction.

\subsection{Frequency effects}

Frequency is a strong predictor for language performance measures. In German, as in many other languages, dative objects are often animate and hence, animacy might be less surprising in a dative object than in an accusative object. Thus, it might be the case that the interaction of object animacy with the case assigned by the verb simply reflects a frequency effect (see, e.g., Levy 2008 for an interesting suggestion of the influence of frequency-related factors on phrasestructure building).

This generalization is relativized in an extensive corpus study (Bader and Häussler 2010) on German sentences. The authors report that datives are indeed animate more often than they are inanimate. However, the authors stress the surprisingly high number of inanimate datives (between 13 and $21 \%$ depending on the corpus, see Bader and Häussler 2010: 16). Another finding that is relevant for the interpretation of our study is that the combination of an animate subject with an animate object is not more frequent with dative than with accusative objects. Therefore, the findings for the specific structures used in our animate conditions do not support the interpretation of our findings as mere effects of frequency. Still, the frequency of a more general pattern (namely, datives are more likely to be animate than accusatives), may have played a role in the comprehension of our stimulus sentences, and may have influenced the EEG pattern, but not the acceptability ratings.

The datives investigated by Bader and Häussler (2010) included the objects in passivized ditransitive constructions, which may have heightened the rate of animate datives compared to the verbs used in our stimulus set. Therefore, caution is needed when applying the results of this corpus study to the interpretation of the findings presented in the current study.

\subsection{Interplay between inherent semantic properties and semantic properties assigned by the verb}

As we outlined in the Introduction, dative-assigning verbs have non-prototypically transitive semantics. It is possible that in general, the inherent semantic properties of animate arguments (their animacy) fit better with the semantic properties 
assigned to the object of a dative verb than with the semantic properties assigned to the object of most accusative verbs. The interaction we find in our ERP study could be caused by the interaction between the objects' animacy and the different degrees of agentivity they have depending on the verb class. This would mean that the modulation of the object animacy effect reflects semantic processing. This explanation runs parallel to findings in sentence production. It is assumed that during sentence production, information that is conceptually more accessible (i.e., easily retrieved) is processed first (Bock and Warren 1985). Therefore, the conceptual accessibility of the referents of possible arguments strongly influences which syntactic structure is going to be produced and which participant is going to be realized as the subject. The conceptual accessibility of a referent, in turn, is a combination of its inherent conceptual accessibility (to which animacy contributes, among other factors) and its derived conceptual accessibility (which is influenced by the discourse context and various other factors in the sentence). Prat-Sala and Branigan (2000) and Branigan et al. (2008) have shown that both kinds of accessibility combine to influence syntactic prominence and word order, and that they interact in complex ways during sentence production. It could be argued that similar processes are at work in sentence comprehension - with an interplay between inherent semantic properties like animacy and derived semantic properties like agentivity - and that it is worthwhile to investigate specific verb-argument-combinations and compare their behaviour in comprehension and production. However, the construction of a truly controlled stimulus set for a study like that would be quite challenging - the number of German non-standard case marking verbs is limited, and further limited by the semantic and thematic restrictions placed on them.

\subsection{Restructuring the syntactic representations}

It is generally assumed that dative is assigned in a different projection than accusative, both for indirect objects of ditransitive verbs and for single objects of noncanonical case marking verbs (e.g., Meinunger 2006; McFadden 2006). Some accounts also suggest that upon encountering a dative verb, the lexical entry of the object NP has to be reaccessed to check for dative morphology, independently of the animacy of the NPs (this explanation was used by Hopf et al. 1998; see also Bayer et al. 2001). This would mean that the parser has to restructure the syntactic representation of the sentence once a dative verb is encountered, and possibly reaccess the lexical entry of the object NP. Under this assumption, our results could be explained as reflecting the additional processing costs caused by the extra workload of rearranging the syntactic representation, and 
of lexical reaccess to check for dative morphology. This process could be reflected in the negativities found after the presentation of the dative verbs in the left-posterior ROI (see Figure 3, panel B), and could be argued to replace or shift the processing of object animacy in the dative condition. This would mean that in the accusative conditions, the negativities represent a true animacy effect. In the dative conditions, however, the negativity is caused by a completely different process that happens to also be reflected in a negativity. The fact that there is no animacy effect on the verb in dative conditions could mean that the animate objects are licensed by dative verbs (again, a more semantically flavored explanation), that the processing of object animacy differences is delayed until the case marking processing is finished, or else, that both processes work in parallel, but their effects on the EEG do not simply add up.

The results of the current study do not allow us to distinguish between these different explanations. Especially the distinction between the second (semantics-based) and third (syntax-based) explanations would be difficult to realize. This has methodological as well as linguistic reasons. Since the non-canonical semantics and non-canonical syntax of dative verbs always go together, there are no dative-assigning verbs with prototypically transitive argument semantics in German. Therefore, the factors "canonical/noncanonical syntax" and "canonical/noncanonical argument semantics" cannot be fully crossed. For potential experiments investigating more subtle semantic distinctions, stimulus construction would be made difficult by the limited number of dative-assigning verbs in German. Since accusative and dative-assigning verbs have to be matched for frequency, length and the selectional restrictions concerning argument semantics (i.e., they all have to allow for animate subjects, and both animate and inanimate objects), this limited set of verbs is further restricted. For any more restricted subgroup of dative verbs, there simply would not be enough verbs left in the German language to build stimulus material for a sound EEG analysis without repeating the same verbs over and over again. While the semantics and syntax of dative verbs remain highly interesting, a new approach will be needed to disentangle the contribution of these two factors to the processing load associated with dative verbs.

\section{Conclusions}

In line with the literature, we found that animate objects cause higher processing costs than inanimate objects in German transitive sentences without overt case marking or number congruency. We found that these effects of object animacy occur even if these sentences are grammatical. We show that the effect 
of object animacy is modulated (i.e., reduced in the left-posterior ROI) if the verb of the sentence has a noncanonical case marking pattern. Noncanonical case marking patterns indicate nonprototypically transitive semantics with more agentive objects. Future research will have to address whether this modulation of the processing of object animacy reflects syntactic or semantic processing, differences in lexical access, or a combination of several factors.

Acknowledgements: We gratefully acknowledge the technical assistance of Carsten Schliewe.

\section{References}

Bader, Markus \& Jana Häussler. 2010. Word order in German: A corpus study. Lingua 120(3). 717-762.

Bader, Markus, Michael Meng \& Josef Bayer. 2000. Case and reanalysis 1. Journal of Psycholinguistic Research 29. 37-53.

Bayer, Josef, Markus Bader \& Michael Meng. 2001. Morphological underspecification meets oblique case: Syntactic and processing effects in German. Lingua 111. 465-514.

Belletti, Adriana \& Luigi Rizzi. 1988. Psych-verbs and theta-theory. Natural Language and Linguistic Theory 6. 291-352.

Blume, Kerstin. 2000. Markierte Valenzen im Sprachvergleich. Tübingen: Max Niemeyer Verlag.

Bock, J. Kathryn. 1986. Syntactic persistence in language production. Cognitive Psychology 18. 355-387.

Bock, J. Kathryn \& Richard Warren. 1985. Conceptual accessibility and syntactic structure in sentence formulation. Cognition 21. 47-67.

Bornkessel, Ina, Brian McElree, Matthias Schlesewsky \& Angela D. Friederici. 2004. Multidimensional contributions to garden path strength: Dissociating phrase structure from case marking. Journal of Memory and Language 51. 495-522.

Bornkessel-Schlesewsky, Ina \& Matthias Schlesewsky. 2006. The extended argument dependency model: A neurocognitive approach to sentence comprehension across languages. Psychological Review 113. 787-821.

Bossong, Georg. 1985. Empirische Universalienforschung: Differentielle Objektmarkierung in den neuiranischen Sprachen. Tübingen: Narr.

Bossong, Georg. 1991. Differential object marking in romance and beyond. In Dieter Wanner \& Douglas A. Kibbee (eds.), New analyses in romance linguistics, 143-170. Amsterdam \& Philadelphia: John Benjamins.

Branigan, Holly P., Martin J. Pickering, Andrew J. Stewart \& Janet F. McLean. 2000. Syntactic priming in spoken production: Linguistic and temporal interference. Journal of Memory and Cognition 28. 1297-1302.

Branigan, Holly P., Martin J. Pickering \& Mikihiro Tanaka. 2008. Contributions of animacy to grammatical function assignment and word order during production. Lingua 118. 172-189.

Brouwer, Harm, Hartmut Fitz \& John Hoeks. 2012. Getting real about semantic illusions: rethinking the functional role of the P600 in language comprehension. Brain research 1446. 127-143. 
Corbett, Greville G. 2000. Number. Cambridge: Cambridge University Press.

Croft, William. 1990. Typology and universals. Cambridge: Cambridge University Press.

Czypionka, Anna. 2014. The interplay of object animacy and verb class in representation

building. Berlin: Humboldt-Universität zu Berlin dissertation.

Dixon, Robert M. W. 1994. Ergativity. Cambridge: Cambridge University Press.

Dowty, David. 1991. Thematic proto-roles and argument selection. Language 67. 547-619.

Fanselow, Gisbert. 2000. Optimal exceptions. In Barbara Stiebels \& Dieter Wunderlich (eds.), Lexicon in focus, 173-209. Berlin: Akademie-Verlag.

Ferreira, Fernanda. 1994. Choice of passive voice is affected by verb type and animacy. Journal of Memory and Language 33. 715-736.

Frazier, Lyn, Lori Taft, Tom Roeper, Charles Clifton \& Kate Erlich. 1984. Parallel structure: A source of facilitation in sentence comprehension. Journal of Memory and Cognition 12. 421-430.

Frisch, Stefan \& Matthias Schlesewsky. 2001. The N400 reflects problems of thematic hierarchizing. NeuroReport 12. 3391-3394.

Grewe, Tanja, Ina Bornkessel-Schlesewsky, Stefan Zysset, Richard Wiese, D. Yves Von Cramon \& Matthias Schlesewsky. 2007. The role of the posterior superior temporal sulcus in the processing of unmarked transitivity. Neurolmage 35. 343-352.

Grimm, Scott. 2010. Semantics of case. Morphology 21. 515-544.

Hagoort, Peter, Colin Brown \& Jolanda Groothusen. 1993. The syntactic positive shift (SPS) as an ERP measure of syntactic processing. Language and cognitive processes 8(4). 439-483.

Haspelmath, Martin. 2013. Occurrence of nominal plurality. In Matthew S. Dryer \& Martin Haspelmath (eds.), The world atlas of language structures online. Leipzig: Max Planck Institute for Evolutionary Anthropology.

Heister, Julian, Kay-Michael Würzner, Johannes Bubenzer, Edmund Pohl, Thomas Hanneforth, Alexander Geyken \& Reinhold Kliegl. 2011. dlexDB - eine lexikalische Datenbank für die psychologische und linguistische Forschung. Psychologische Rundschau 32. 10-20.

Hoeks, John C.J., Laurie Stowe \& Gina Doedens. 2004. Seeing words in context: The interaction of lexical and sentence level information during reading. Cognitive Brain Research 19. 59-73.

Hopf, Jens-Max, Josef Bayer, Markus Bader \& Michael Meng. 1998. Event-related brain potentials and case information in syntactic ambiguities. Journal of Cognitive Neuroscience 10. 264-280.

Jäger, Gerhardt. 2004. Learning constraint sub-hierarchies: The bidirectional gradual learning algorithm. In Reinhard Blutner \& Henk Zeevat (eds.), Optimality theory and pragmatics, 442-501. Basingstoke: Palgrave McMillan.

Kim, Albert \& Lee Osterhout. 2005. The independence of combinatory semantic processing: Evidence from event-related potentials. Journal of Memory and Language 52. 205-225.

Krifka, Manfred. 2009. Case syncretism in German feminines: Typological, functional and structural aspects. In Manfred Krifka \& Patrick Steinkrüger (eds.), On inflection, 141-172. Berlin \& New York: Mouton de Gruyter.

Kuperberg, Gina R. 2007. Neural mechanisms of language comprehension: Challenges to syntax. Brain Research 1146. 23-49.

Kuperberg, Gina R., Donna A. Kreher, Tatiana Sitnikova, David N. Caplan \& Phillip J. Holcomb. 2007. The role of animacy and thematic relationships in processing active English sentences: Evidence from event-related potentials. Brain and Language 100. 223-237. 
Kuperberg, Gina R., Tatiana Sitnikova, David N. Caplan \& Phillip J. Holcomb. 2003.

Electrophysiological distinctions in processing conceptual relationships within simple sentences. Cognitive Brain Research 17. 117-129.

Kuperberg, Gina R., Tatiana Sitnikova, Mariana Eddy \& Phillip J. Holcomb. 2006. Neural correlates of processing syntactic, semantic and thematic relationships in sentences. Language and Cognitive Processes 21. 117-129.

Kutas, Marta \& Steven A. Hillyard. 1980. Reading senseless sentences: Brain potentials reflect semantic incongruity. Science 207(4427). 203-205.

Kutas, Marta \& Steven A. Hillyard. 1982. The lateral distribution of event-related potentials during sentence processing. Neuropsychologia 20. 579-590.

Kutas, Marta, Cyma K. Van Petten \& Robert Kluender. 2006. Psycholinguistics electrified II (1994-2005). In Matthew Traxler \& Morton Gernsbacher (eds.), Handbook of psycholinguistics, 2nd edn., 659-724. New York: Academic Press.

Ledoux, Kerry, Matthew J. Traxler \& Tamara Y. Swaab. 2007. Syntactic priming in comprehension: Evidence from event-related potentials. Psychological Science 18(2). 135-143.

Levin, Beth. 1993. English verb classes and alternations - A preliminary investigation. Chicago, IL: University of Chicago Press.

Levy, Roger. 2008. Expectation-based syntactic comprehension. Cognition 106. 1126-1177.

Malchukov, Andrej L. 2008. Animacy and asymmetries in differential case marking. Lingua 118 (2). 203-221.

McFadden, Thomas. 2004. The position of morphological case in the derivation: A study on the syntax-morphology interface. Philadelphia, PA: University of Pennsylvania dissertation.

McFadden, Thomas. 2006. German inherent datives and argument structure. In Daniel Hole, André Meinunger \& Werner Abraham (eds.), Datives and other cases, 49-78. Amsterdam \& Philadelphia: John Benjamins.

Meinunger, André. 2006. Remarks on the projection of dative arguments in German. In Daniel Hole, André Meinunger \& Werner Abraham (eds.), Datives and other cases, 50-79. Amsterdam \& Philadelphia: John Benjamins.

Meinunger, André. 2007. Der Dativ im Deutschen - Eine Verständnishilfe für das Phänomen der gespaltenen Ergativität. Linguistische Berichte 209. 3-33.

Naess, Åshild 2004. What markedness marks: The markedness problem with direct objects. Lingua 114. 1186-1212.

Osterhout, Lee \& Phillip J. Holcomb. 1992. Event-related brain potentials elicited by syntactic anomaly. Journal of Memory and Language 31(6). 785-806.

Paczynski, Martin \& Gina R. Kuperberg. 2009. The impact of grammatical voice and subject noun animacy on verb processing. Paper presented at the Neurobiology of Language Conference, University of Chicago, 15-16 October.

Paczynski, Martin \& Gina R. Kuperberg. 2011. Electrophysiological evidence for use of the animacy hierarchy, but not thematic role assignment, during verb-argument processing. Language and Cognitive Processes 26(9). 1402-1456.

Prat-Sala, Mercè \& Holly P. Branigan. 2000. Discourse constraints on syntactic processing in language production: A cross-linguistic study in English and Spanish. Journal of Memory and Language 42(2). 168-182. 
Sassenhagen, Jona, Matthias Schlesewsky \& Ina Bornkessel-Schlesewsky. 2014. On incremental interpretation: Degrees of meaning accessed during sentence comprehension. Brain and Language 114. 29-39.

Silverstein, M. 1976. Hierarchy of features and ergativity. In Robert M. W. Dixon (ed.), Grammatical categories in Australian languages, 112-171. Canberra: Australian Institute of Aboriginal Studies.

Trueswell, John C., Michael K. Tanenhaus \& Susan M. Garnsey. 1994. Semantic influences on parsing: Use of thematic role information in syntactic ambiguity resolution. Journal of Memory and Language 33. 285-318.

van Nice, Kathy Y. \& Rainer Dietrich. 2003. Task sensitivity of animacy effects: Evidence from German picture descriptions. Linguistics 41. 825-849.

Wechsler, Stephen. 1995. The semantic basis of argument structure. Stanford, CA: CSLI Publications.

Weckerly, Jill \& Marta Kutas. 1999. An electrophysiological analysis of animacy effects in the processing of object relative sentences. Psychophysiology 36. 559-570.

Woolford, Ellen. 2006. Lexical case, inherent case, and argument structure. Linguistic Inquiry 37. 111-130.

\section{Appendix. Stimuli}

This Appendix lists all critical sentences used in the experiment.

(1) a: inanimate-accusative

Kathrin behauptet, dass Banditen Postkutschen häufig

Kathrin claims that bandit.PL.(NOM) stagecoach.PL.(ACC) frequently ausrauben, und Max behauptet das auch.

rob.3PL and Max claims that too

'Kathrin claims that bandits frequently rob stage coaches, and Max claims that too.'

b: animate-accusative

Samira behauptet, dass Banditen Postboten häufig

Samira claims that bandit.PL.(NOM) postman.PL.(ACC) frequently ausrauben, und Emma behauptet das auch.

rob.3PL and Emma claims that too

'Samira claims that bandits frequently rob postmen, and Emma claims that, too.'

c: inanimate-dative

Daniel behauptet, dass Banditen Postkutschen

Daniel claims that bandit.PL.(NOM) stagecoach.PL.(DAT) 
häufig auflauern, und Dominik behauptet das auch.

frequently waylay.3PL and Dominik claims that too

'Daniel claims that bandits frequently waylay stage coaches, and Dominik claims that, too.'

$\mathrm{d}$ : animate-dative

Tommi behauptet, dass

Banditen

Postboten

Tommi claims that

bandit.PL.(NOM) postman.PL.(DAT)

häufig auflauern, und Susanne behauptet das auch.

frequently waylay.3PL and Susanne claims that too

'Tommi claims that bandits frequently waylay postmen, and Susanne claims that, too.'

(2) a: inanimate-accusative

Peter behauptet, dass Studentinnen Vorlesungen

Peter claims that student.FEM.PL.(NOM) lecture.PL.(ACC)

begeistert loben, und Ida behauptet das auch.

enthusiastically praise.3PL and Ida claims that too

'Peter claims that students enthusiastically praise lectures, and Ida claims that, too.'

b: animate-accusative

Sven behauptet, dass Studentinnen Professoren

Sven claims that student.FEM.PL.(NOM) professor.PL.(ACC)

begeistert loben, und Ida behauptet das auch.

enthusiastically praise.3PL and Ida claims that too

'Sven claims that students enthusiastically praise professors, and Andreas claims that, too.'

c: inanimate-dative

Mia behauptet, dass Studentinnen Vorlesungen

Mia claims that student.FEM.PL.(NOM) lecture.PL.(DAT)

begeistert applaudieren und Jan behauptet das auch..

enthusiastically applaud.3PL and Jan claims that too

'Mia claims that students enthusiastically applaud lectures, and Jan claims that, too.'

$\mathrm{d}$ : animate-dative

Jan behauptet, dass Studentinnen Professoren

Jan claims that student.FEM.PL.(NOM) professor.PL.(DAT)

begeistert applaudieren und Tim behauptet das auch..

enthusiastically applaud.3PL and Tim claims that too

'Jan claims that students enthusiastically applaud professors, and Tim claims that, too.' 
(3) a: inanimate-accusative

Leo denkt, dass Direktoren Strategien schnell

Leo thinks that director.PL.(NOM) strategy.PL.(ACC) quickly

verstehen, und Bert denkt das gleiche.

understand.3PL and Ida claims that too

'Leo thinks that directors quickly understand strategies and Bernd thinks so, too.'

b: animate-accusative

Lydia denkt, dass Direktoren Sekretärinnen schnell

Lydia thinks that director.PL.(NOM) secretary.FEM.PL.(ACC) quickly verstehen, und Jan denkt das gleiche.

understand.3PL and Jan claims that too

'Lydia thinks that directors quickly understand secretaries and Jan thinks so, too.'

c: inanimate-dative

Jakob denkt, dass Direktoren Strategien schnell

Jakob thinks that director.PL.(NOM) strategy.PL.(DAT) quickly

zustimmen, und Hannah denkt das gleiche.

agree.with.3PL and Hannah claims that too

'Jakob thinks that directors quickly agree with strategies, and Hannah

thinks so, too.'

d: animate-accusative

Sabrina denkt, dass Direktoren Sekretärinnen schnell

Sabrina thinks that director.PL.(NOM) secretary.FEM.PL.(DAT) quickly zustimmen, und Simone denkt das gleiche.

agree.with.3PL and Simone claims that too

'Sabrina thinks that directors quickly agree with secretaries and Simone thinks so, too.'

(4) a: inanimate-accusative

Kerstin glaubt, dass Sängerinnen

Anfeindungen gelassen

Kerstin believes that singer.FEM.PL.(NOM) hostility.PL.(ACC) calmly

aushalten, und Miriam glaubt das auch.

endure.3PL and Miriam believes that too

'Kerstin believes that singers calmly bear hostilities, and Miriam believes it, too.'

b: animate-accusative

Kilian glaubt, dass Sängerinnen Dirigenten gelassen

Kilian believes that singer.FEM.PL.(NOM) conductor.PL.(ACC) calmly 
aushalten, und Anna glaubt das auch.

endure.3PL and Anna believes that too

'Kilian believes that singers calmly bear conductors, and Anna believes that, too.'

c: inanimate-dative

Mirka glaubt, dass Sängerinnen Anfeindungen gelassen

Mirka believes that singer.FEM.PL.(NOM) hostility.PL.(DAT) calmly

standhalten, und Johanna glaubt das auch.

resist.3PL and Johanna believes that too.

'Mirka believes that singers calmly resist hostilities, and Johanna believes that, too.'

$\mathrm{d}$ : animate-dative

Paul glaubt, dass Sängerinnen Dirigenten gelassen

Paul believes that singer.FEM.PL.(NOM) conductor.PL.(DAT) calmly

standhalten, und Alex glaubt das auch.

resist.3PL and Alex believes that too.

'Paul believes that singers calmly resist conductors, and Alex believes that, too.'

(5) a: inanimate-accusative

Kati berichtet, dass Allergikerinnen Zigaretten

Kati relates that allergic.person.FEM.PL.(NOM) cigarette.PL.(ACC)

häufig verfluchen, und Mari berichtet das auch.

frequently curse.3PL and Mari relates that too.

'Kati tells that allergic people frequently curse cigarettes, and Mari tells the same.'

b: animate-accusative

Rita berichtet, dass Allergikerinnen Katzen

Kati relates that allergic.person.FEM.PL.(NOM) cat.PL.(ACC)

häufig verfluchen, und Mari berichtet das auch.

frequently curse.3PL and Fred relates that too.

'Rita tells that allergic people frequently curse cats, and Fred tells the same.'

c: inanimate-dative

Egon berichtet, dass Allergikerinnen Zigaretten

Egon relates that allergic.person.FEM.PL.(NOM) cigarette.PL.(DAT)

häufig abschwören, und Simon berichtet das auch.

frequently swear.off.3PL and Simon relates that too.

'Egon tells that allergic people often swear off cigarettes, and Simon tells the same.' 
c: animate-dative

Henk berichtet, dass Allergikerinnen Katzen

Henk relates that allergic.person.FEM.PL.(NOM) cat.PL.(DAT)

häufig abschwören, und Nele berichtet das auch.

frequently swear.off.3PL and Nele relates that too.

'Henk tells that allergic people often swear off cats, and Nele tells the same.'

(6) a: inanimate-accusative

Tim glaubt, dass Tauben Luftballons gerne

Tim believes that dove.PL.(NOM) airballoon.PL.(ACC) gladly

mögen und Tom glaubt das auch.

like.3PL and Tom believes that too

'Tim believes that doves rather like balloons, and Tom believes that, too.'

b: animate-accusative

Julian glaubt, dass Tauben Krähen gerne

Julian believes that dove.PL.(NOM) crow.PL.(ACC) gladly

mögen und Horst glaubt das auch.

like.3PL and Horst believes that too

'Julian believes that doves rather like crows, and Horst believes that, too.'

c: inanimate-dative

Gabi glaubt, dass Tauben Luftballons gerne

Gabi believes that dove.PL.(NOM) airballoon.PL.(DAT) gladly

folgen und Else glaubt das auch.

follow.3PL and Else believes that too

'Gabi believes that doves like following balloons, and Else believes that, too.'

d: animate-dative

Tim glaubt, dass Tauben Krähen gerne

Tim believes that dove.PL.(NOM) airballoon.PL.(DAT) gladly

folgen und Tom glaubt das auch.

follow.3PL and Tom believes that too

'Tim believes that doves like following crows, and Tom believes that, too.'

(7) a: inanimate-accusative

Suse behauptet, dass Richterinnen Alibis häufig

Suse claims that judge.FEM.PL.(NOM) alibi.PL.(ACC) frequently 
ablehnen, und Freddie behauptet das gleiche.

reject.3PL and Freddie claims that too

'Suse claims that judges frequently reject alibis, and Freddie claims that, too.'

b: animate-accusative

Manuela behauptet, dass Richterinnen Zeuginnen

Manuela claims that judge.FEM.PL.(NOM) witness.FEM.PL.(ACC)

häufig ablehnen, und Torsten behauptet das gleiche.

frequently reject.3PL and Torsten claims that too

'Manuela claims that judges frequently reject witnesses, and Torsten claims that, too.'

c: inanimate-dative

Frieke behauptet, dass Richterinnen Alibis häufig

Frieke claims that judge.FEM.PL.(NOM) alibi.PL.(DAT) frequently

misstrauen, und Anna behauptet das gleiche.

distrust.3PL and Anna claims that too

'Frieke claims that judges frequently distrust alibis, and Anna claims that, too.'

$\mathrm{d}$ : animate-dative

Nadja behauptet, dass Richterinnen Zeuginnen

Nadja claims that judge.FEM.PL.(NOM) witness.FEM.PL.(DAT)

häufig misstrauen, und Linus behauptet das gleiche.

frequently distrust.3PL and Linus claims that too

'Nadja claims that judges frequently distrust witnesses, and Linus claims that, too.'

(8) a: inanimate-accusative

Marion sagt, dass Sekretärinnen Firmen

Marion says that secretary.FEM.PL.(NOM) company.PL.(DAT)

ungern anzeigen, und Karla sagt das gleiche.

reluctantly report.3PL and Karla says the same

'Marion says that secretaries dislike reporting companies [to the police], and Karla says so, too.'

b: animate-accusative

Henning sagt, dass Sekretärinnen Kollegen

Henning says that secretary.FEM.PL.(NOM) colleagues.PL.(DAT)

ungern anzeigen, und Hannes sagt das gleiche.

reluctantly report.3PL and Hannes says the same

'Henning says that secretaries dislike reporting colleagues [to the police], and Hannes says so, too.' 
c: inanimate-dative:

Ute sagt, dass Sekretärinnen Firmen ungern

Ute says that secretary.FEM.PL.(NOM) company.PL.(DAT) reluctantly schaden, und Elke sagt das gleiche.

damage.3PL and Elke says the same

'Ute says that secretaries dislike doing damage to companies, and Elke says the same.'

$\mathrm{d}$ : animate-dative

Udo sagt, dass Sekretärinnen Kollegen

Udo says that secretary.FEM.PL.(NOM) colleagues.PL.(DAT)

ungern schaden, und Simone sagt das gleiche.

reluctantly damage.3PL and Simone says the same

'Udo says that secretaries dislike doing damage to colleagues, and Simone says so, too.'

(9) a: inanimate-accusative

Teresa erzählt, dass Mädchen Karnevalswagen

Teresa tells that girl.PL.(NOM) carnival.wagon.PL.(ACC)

begeistert anstarren, und Roland erzählt das gleiche.

enthusiastically stare.at.3PL and Roland tells the same

'Teresa tells that girls enthusiastically stare at carnival floats, and Roland tells the same.'

b: animate-accusative

Peter erzählt, dass Mädchen Karnevalsprinzen

Peter tells that girl.PL.(NOM) carnival.prince..PL.(ACC)

begeistert anstarren, und Lisa erzählt das gleiche.

enthusiastically stare.at.3PL and Lisa tells the same

'Peter tells that girls enthusiastically stare at carnival princes, and Lisa tells the same.'

c: inanimate-dative

Hannes erzählt, dass Mädchen Karnevalswagen

Hannes tells that girl.PL.(NOM) carnival.wagon..PL.(DAT)

begeistert zujubeln, und Malte erzählt das gleiche.

enthusiastically cheer.at.3PL and Malte tells the same

'Hannes tells that girls enthusiastically hail carnival floats, and Malte tells the same.'

$\mathrm{d}$ : animate-dative

Antje erzählt, dass Mädchen Karnevalsprinzen

Antje tells that girl.PL.(NOM) carnival.prince..PL.(DAT) 
begeistert zujubeln, und Mareike erzählt das gleiche.

enthusiastically cheer.at.3PL and Mareike tells the same

'Antje tells that girls enthusiastically hail carnival princes, and Mareike tells the same.'

(10) a: inanimate-accusative

Nina sagt, dass Mädchen Autos lange

Nina says that girl.PL.(NOM) car.PL.(ACC) long

anglotzen, und Hans sagt das auch.

stare.at.3PL and Hans says that too

'Nina says that girls stare at cars for a long time, and Hans says so, too.'

b: animate-accusative

Florian sagt, dass Mädchen Jungen lange anglotzen,

Florian says that girl.PL.(NOM) boy.PL.(ACC) long stare.at.3PL

und Felix sagt das auch.

and Felix says that too

'Florian says that girls stare at boys for a long time, and Felix says so, too.'

c: inanimate-dative

Antje sagt, dass Mädchen Autos lange

Antje says that girl.PL.(NOM) car.PL.(DAT) long

nachglotzen und Kerstin sagt das auch.

stare.after.3PL and Kerstin says that too

'Antje says that girls stare after cars for a long time, and Kerstin says so, too.'

$\mathrm{d}$ : animate-dative

Sabine sagt, dass Mädchen Jungen lange

Sabine says that girl.PL.(NOM) boy.PL.(DAT) long

nachglotzen und Anne sagt das auch.

stare.after.3PL and Anne says that too

'Sabine says that girls stare after boys for a long time, and Anne says so, too.'

(11) a: inanimate-accusative

Kathrin erzählt, dass Krähen Luftballons misstrauisch

Kathrin tells that crow.PL.(NOM) air.balloon.PL.(ACC) suspiciously anglotzen, und Maja erzählt das auch.

stare.at.3PL and Maja tells that too

'Kathrin tells that crows suspiciously watch balloons, and Maja tells that, too.' 
b: animate-accusative

Anja erzählt, dass Krähen Eulen misstrauisch

Anja tells that crow.PL.(NOM) owl.PL.(ACC) suspiciously

anglotzen, und Thomas erzählt das auch.

stare.at.3PL and Thomas tells that too

'Anja tells that crows suspiciously watch owls, and Thomas tells that, too.'

c: inanimate-dative

Vera erzählt, dass Krähen Luftballons misstrauisch

Vera tells that crow.PL.(NOM) air.balloon.PL.(DAT) suspiciously nachsehen und Peter erzählt das auch.

watch.after.3PL and Peter tells that too

'Vera tells that crows suspicously look after balloons [that move away] and Peter tells that, too.'

$\mathrm{d}$ : animate-dative

Ute erzählt, dass Krähen Eulen misstrauisch

Ute tells that crow.PL.(NOM) owl.PL.(DAT) suspiciously

nachsehen und Elke erzählt das auch.

watch.after.3PL and Elke tells that too

'Ute tells that crows suspiciously look after owls [that move away] and Elke tells that, too.'

(12) a: inanimate-accusative

Florian meint, dass Ärztinnen Irlehren

Florian supposes that doctor.FEM.PL.(NOM) heterodoxy.PL.(ACC)

nachdrücklich verteidigen, und Petra meint das auch.

insistently defend.3PL and Petra supposes that too

'Florian supposes that doctors insistently defend heterodoxies, and Petra supposes so to.'

b: animate-accusative

Ana meint, dass Ärztinnen Krankenpflegerinnen

Ana supposes that doctor.FEM.PL.(NOM) nurse.FEM.PL.(ACC)

nachdrücklich verteidigen, und Max meint das auch.

insistently defend.3PL and Max supposes that too

'Ana supposes that doctors insistently defend nurses, and Max supposes so too.'

c: inanimate-dative

Gabi meint, dass Ärztinnen Irrlehren

Gabi supposes that doctor.FEM.PL.(NOM) heterodoxy.PL.(DAT) 
nachdrücklich widersprechen und Andrea meint das auch. insistently contradict.3PL and Andrea supposes that too 'Gabi supposes that doctors emphatically contradict heterodoxies, and Andrea supposes so, too.'

$\mathrm{d}$ : animate-dative

Rudi meint, dass Ärztinnen Krankenpflegerinnen

Rudi supposes that doctor.FEM.PL.(NOM) nurse.FEM.PL.(DAT)

nachdrücklich widersprechen und Pia meint das auch.

insistently contradict.3PL and Pia supposes that too

'Rudi supposes that doctors emphatically contradict nurses, and Pia supposes so, too.'

(13) a: inanimate-accusative

Norbert hofft, dass Politikerinnen Bestechungen

Norbert hopes that politician.FEM.PL.(NOM) bribe.PL.(ACC)

prinzipiell ablehnen, und Karin hofft das auch.

on.principle reject.3PL and Karin hopes that too

'Norbert hopes that politicians reject of bribes as a matter of principle, and Karin hopes so, too.'

b: animate-accusative

Toni hofft, dass Politikerinnen Baulöwen

Toni hopes that politician.FEM.PL.(NOM) build.lion.PL.(ACC)

prinzipiell ablehnen, und Michael hofft das auch.

on.principle reject.3PL and Michael hopes that too

'Toni hopes that politicians reject building tycoons as a matter of principle, and Michael hopes so, too.'

c: inanimate-dative

Vroni hofft, dass Politikerinnen Bestechungen problemlos

Vroni hopes that politician.FEM.PL.(NOM) bribe.PL.(DAT) problem.less

widerstehen, und Karin hofft das auch.

resist.3PL and Karin hopes that too

'Vroni hopes that politicians resist bribes without difficulty and Karin hopes so, too.'

$\mathrm{d}$ : animate-dative

Emanuel hofft, dass Politikerinnen Baulöwen

Emanuel hopes that politician.FEM.PL.(NOM) build.lion.PL.(DAT)

problemlos widerstehen, und Saskia hofft das auch.

problem.less resist.3PL and Saskia hopes that too

'Emanuel hopes that politicians resist building tycoons without difficulty and Saskia hopes so, too.' 
(14) a: inanimate-accusative

Nicole denkt, dass Schülerinnen Unannehmlichkeiten

Nicole thinks that pupil.FEM.PL.(NOM) inconvenience.PL.(ACC)

selten vergessen und Daniel denkt es auch.

rarely forget.3PL and Daniel thinks it too

'Nicole thinks that pupils rarely forget inconveniences, and Daniel thinks so, too.'

b: animate-accusative

Michael denkt, dass Schülerinnen Lehrerinnen selten

Michael thinks that pupil.FEM.PL.(NOM) teacher.FEM.PL.(ACC) rarely vergessen und Claudia denkt es auch.

forget.3PL and Claudia thinks it too

'Michael thinks that pupils rarely forget teachers, and Claudia thinks so, too.'

c: inanimate-dative

Jessica denkt, dass Schülerinnen Unannehmlichkeiten selten

Jessica thinks that pupil.FEM.PL.(NOM) inconvenience.PL.(DAT) rarely begegnen und Dominik denkt es auch.

encounter.3PL and Dominik thinks it too

'Jessica thinks that pupils rarely encounter inconveniences, and Dominik thinks so, too.'

$\mathrm{d}$ : animate-dative

Marina denkt, dass Schülerinnen Lehrerinnen selten

Marina thinks that pupil.FEM.PL.(NOM) teacher.FEM.PL.(DAT) rarely begegnen und Wolfgang denkt es auch.

encounter.3PL and Wolfgang thinks it too

'Marina thinks that pupils rarely encounter teachers, and Wolfgang thinks so,too.'

(15) a: inanimate-accusative

Matthias hofft, dass Patienten Anweisungen selten

Matthias hopes that patient.PL.(NOM) instruction.PL.(ACC) rarely verspotten und Tina hofft es auch.

mock.3PL and Tina hopes it too

'Matthias hopes that patients rarely mock [doctor's] orders, and Tina hopes so, too.'

b: animate-accusative

Julia hofft, dass Patienten Arztinnen selten

Julia hopes that patient.PL.(NOM) doctor.FEM.PL.(ACC) rarely 
verspotten und Karsten hofft es auch.

mock.3PL and Karsten hopes it too

'Julia hopes that patients rarely mock doctors, and Karsten hopes so, too.'

c: inanimate-dative

Robert hofft, dass Patienten Anweisungen selten

Robert hopes that patient.PL.(NOM) instruction.PL.(DAT) rarely

zuwiderhandeln und Nele hofft es auch.

counteract.3PL and Nele hopes it too

'Robert hopes that patients rarely act against [doctor's] orders, and Nele hopes so, too.'

$\mathrm{d}$ : animate-dative

Benno hofft, dass Patienten Arztinnen selten

Benno hopes that patient.PL.(NOM) doctor.FEM.PL.(DAT) rarely

zuwiderhandeln und Sina hofft es auch.

counteract.3PL and Sina hopes it too

'Benno hopes that patients rarely act against doctors, and Sina hopes so, too.'

(16) a: inanimate-accusative

Karsten sieht, dass Radfahrerinnen Baustellen geschickt

Karsten sees that cyclist.FEM.PL.(NOM) build.site.PL.(ACC) deftly vermeiden und Martin sieht das auch.

avoid.3PL and Martin sees it, too

'Karsten sees that cyclists deftly avoid construction sites, and Martin sees it, too.'

b: animate-accusative

Toni sieht, dass Radfahrerinnen Polizisten geschickt

Toni sees that cyclist.FEM.PL.(NOM) policeman.PL.(ACC) deftly

vermeiden und Suse sieht das auch.

avoid.3PL and Suse sees it, too

'Toni sees that cyclists deftly avoid policemen, and Suse sees it, too.'

c: inanimate-dative

Otto sieht, dass Radfahrerinnen Baustellen geschickt

Otto sees that cyclist.FEM.PL.(NOM) build.site.PL.(DAT) deftly

ausweichen und Rainer sieht das auch.

dodge.3PL and Rainer sees it, too

'Otto sees that cyclists deftly dodge construction sites, and Rainer sees it, too.' 
$\mathrm{d}$ : animate-dative

Michael sieht, dass Radfahrerinnen Polizisten geschickt

Michael sees that cyclist.FEM.PL.(NOM) policeman.PL.(DAT) deftly ausweichen und Andreas sieht das auch.

dodge.3PL and Andreas sees it, too

'Michael sees that cyclists deftly dodge policemen, and Andreas sees it, too.'

(17) a: inanimate-accusative

Robert hofft, dass Eltern Beschwerden aufmerksam

Robert hopes that parent.PL.(NOM) complaint..PL.(ACC) attentitvely anhören und Max hofft das auch.

listen.to.3PL and Max hopes that too

'Robert hopes that parents attentively listen to complaints, and Max hopes so,too.'

b: animate-accusative

Lena hofft, dass Eltern Lehrerinnen aufmerksam

Lena hopes that parent.PL.(NOM) teacher.FEM.PL.(ACC) attentitvely

anhören und Miriam hofft das auch.

listen.to.3PL and Miriam hopes that too

'Lena hopes that parents attentively listen to teachers, and Miriam hopes so, too.'

c: inanimate-dative

Björn hofft, dass Eltern Beschwerden aufmerksam

Björn hopes that parent.PL.(NOM) complaint..PL.(DAT) attentitvely

zuhören und Anna hofft das auch.

listen.to.3PL and Anna hopes that too

'Björn hopes that parents attentively listen to complaints, and Anna hopes so, too.'

$\mathrm{d}$ : animate-dative

Hannes hofft, dass Eltern Lehrerinnen aufmerksam

Hannes hopes that parent.PL.(NOM) teacher.FEM.PL.(DAT) attentitvely zuhören und Katja hofft das auch.

listen.to.3PL and Katja hopes that too

'Hannes hopes that parents attentively listen to teachers, and Katja hopes so, too.'

(18) a: inanimate-accusative

Nora erzählt, dass Jungen Autos neugierig

Nora tells that boy.PL.(NOM) car.PL.(ACC) curiously 
anstarren, und Gabi erzählt das gleiche.

stare.at.3PL and Gabi tells the same

'Nora tells that boys curiously stare at cars and Gabi tells the same.'

b: animate-accusative

Dirk erzählt, dass Jungen Mädchen neugierig

Dirk tells that boy.PL.(NOM) girl.PL.(ACC) curiously

anstarren, und Nicole erzählt das gleiche.

stare.at.3PL and Nicole tells the same

'Dirk tells that boys curiously stare at girls, and Nicole tells the same.'

c: inanimate-dative

Nadine erzählt, dass Jungen Autos neugierig

Nadine tells that boy.PL.(NOM) car.PL.(DAT) curiously

nachlaufen, und Jessica erzählt das gleiche.

run.after.3PL and Jessica tells the same

'Nadine tells that boys curiously run after cars, and Jessica tells the same.'

$\mathrm{d}$ : animate-dative

Dieter erzählt, dass Jungen Mädchen neugierig

Dieter tells that boy.PL.(NOM) girl.PL.(DAT) rarely

nachlaufen, und Andreas erzählt das gleiche.

run.after.3PL and Andreas tells the same

'Dieter tells that boys curiously run after girls, and Andreas tells the same.'

(19) a: inanimate-accusative

Thomas erzählt, dass Katzen Tierparks selten

Thomas tells that cat.PL.(NOM) zoo.PL.(ACC) rarely

akzeptieren, und Matti erzählt das gleiche.

accept.3PL and Matti tells the same

'Thomas tells that cats rarely accept zoos and Matti tells the same.'

b: animate-accusative

Roland erzählt, dass Katzen Frauchen selten

Roland tells that cat.PL.(NOM) woman.DIM.PL.(ACC) rarely

akzeptieren, und Sabine erzählt das gleiche.

accept.3PL and Sabine tells the same

'Roland tells that cats rarely accept (female) owners, and Sabine tells the same.'

c: inanimate-dative

Willi erzählt, dass Katzen Tierparks selten

Willi tells that cat.PL.(NOM) zoo.PL.(DAT) rarely 
entlaufen, und Artur erzählt das gleiche.

run.off.3PL and Artur tells the same

'Willi tells that cats rarely run away from zoos, and Artur tells the same.'

d: animate-dative

Nicole erzählt, dass Katzen Frauchen selten

Nicole tells that cat.PL.(NOM) woman.DIM.PL.(DAT) rarely

entlaufen, und Jens erzählt das gleiche.

run.off.3PL and Jens tells the same

'Nicole tells that cats rarely run away from (female) owners, and Jens tells the same.'

(20) a: inanimate-accusative

Jana sagt, dass Schülerinnen Einladungen gerne

Jana says that pupil.FEM.PL.(NOM) invitation.PL.(ACC) gladly

annehmen, und Mirko sagt das auch.

accept.3PL and Mirko tells the same

'Jana says that pupils like accepting invitations, and Mirko says so, too.'

b: animate-accusative

Matthias sagt, dass Schülerinnen Lehrerinnen gerne

Matthias says that pupil.FEM.PL.(NOM) teacher.FEM.PL.(ACC) gladly

annehmen, und Felix sagt das auch.

accept.3PL and Felix tells the same

'Matthias says that pupils like accepting teachers, and Felix says so, too.'

c: inanimate-dative

Peter sagt, dass Schülerinnen Einladungen gerne

Peter says that pupil.FEM.PL.(NOM) invitation.PL.(DAT) gladly

entgegenkommen, und Stefan sagt das auch.

come.toward.3PL and Stefan tells the same

'Peter says that pupils like to accomodate to invitations and Stefan says so, too.'

$\mathrm{d}$ : animate-dative

Karl sagt, dass Schülerinnen Lehrerinnen gerne

Karl says that pupil.FEM.PL.(NOM) teacher.FEM.PL.(DAT) gladly

entgegenkommen, und Lars sagt das auch.

come.toward.3PL and Lars tells the same

'Karl says that pupils gladly accommodate to teachers, and Lars says so, too.' 
(21) a: inanimate-accusative

Merle behauptet, dass Waisen Sonderschulen

Merle claims that orphan.PL.(NOM) special.school.PL.(ACC)

niemals fürchten, und Wiebke behauptet das auch.

never fear.3PL and Wiebke tells the same

'Merle claims that orphans never fear special schools, and Wiebke claims the same.'

b: animate-accusative

Heidi behauptet, dass Waisen Betreuerinnen

Heidi claims that orphan.PL.(NOM) custodian.FEM.PL.(ACC)

niemals fürchten, und Greta behauptet das auch.

never fear.3PL and Greta tells the same

'Heidi claims that orphans never fear custodians, and Greta claims the same.'

c: inanimate-dative

Jutta behauptet, dass Waisen Sonderschulen

Jutta claims that orphan.PL.(NOM) special.school.PL.(DAT)

niemals entkommen, und Roland behauptet das auch.

never escape.3PL and Roland tells the same

'Jutta claims that orphans never escape special schools, and Roland claims the same.'

d: animate-accusative

Robert behauptet, dass Waisen Betreuerinnen

Robert claims that orphan.PL.(NOM) custodian.FEM.PL.(DAT)

niemals entkommen, und Antje behauptet das auch.

never escape.3PL and Antje tells the same

'Robert claims that orphans never escape custodians, and Antje claims the same.'

(22) a: inanimate-accusative

Tina beklagt, dass Journalisten Parteien regelmäßig

Tina laments that journalist.PL.(NOM) party.PL.(ACC) regularly parodieren, und Petra beklagt es auch.

parody.3PL and Petra laments it too

'Tina laments that journalists regularly spoof [political] parties, and Petra laments it, too.'

b: animate-accusative

Hannes beklagt, dass Journalisten Kollegen

Hannes laments that journalist.PL.(NOM) colleague.PL.(ACC) 
regelmäßig parodieren, und Volker beklagt es auch. regularly parody.3PL and Volker laments it too 'Hannes laments that journalists regularly spoof colleagues, and Volker laments it, too.'

c: inanimate-dative

Wolfgang beklagt, dass Journalisten Parteien regelmäßig Wolfgang laments that journalist.PL.(NOM) party.PL.(DAT) regularly zuvorkommen, und Claudia beklagt es auch. scoop.3PL and Claudia laments it too 'Wolfgang laments that journalists regularly scoop [political] parties, and Claudia laments it, too.'

$\mathrm{d}$ : animate-dative

Britta beklagt, dass Journalisten Kollegen

Britta laments that journalist.PL.(NOM) colleague.PL.(DAT)

regelmäßig zuvorkommen, und Inge beklagt es auch. regularly scoop.3PL and Inge laments it too 'Britta laments that journalists regularly scoop colleagues, and Inge laments it, too.'

(23) a: inanimate-accusative

Jonna hofft, dass Beraterinnen

Parteien

Jonna hopes that consultant.FEM.PL.(NOM) colleague.PL.(ACC)

engagiert unterstützen, und Nils hofft das auch.

committedly support.3PL and Nils laments it too

'Jonna hopes that consultants committedly support [political] parties, and Nils hopes so, too.'

b: animate-accusative

Inge hofft, dass Beraterinnen

Kandidaten

Inge hofft that consultant.FEM.PL.(NOM) candidate.PL.(ACC)

engagiert unterstützen, und Michael hofft das auch.

committedly support.3PL and Michael laments it too

'Ingo hopes that consultants committedly support candidates, and Michael hopes so, too.'

c: inanimate-dative

Britta hofft, dass Beraterinnen Parteien

Britta hofft that consultant.FEM.PL.(NOM) colleague.PL.(ACC)

engagiert dienen, und Jannis hofft das auch.

committedly serve.3PL and Jannis laments it too

'Britta hopes that consultants committedly serve [political] parties, and Jannis hopes so, too.’ 
$\mathrm{d}$ : animate-dative

Joachim hofft, dass Beraterinnen Kandidaten

Joachim hofft that consultant.FEM.PL.(NOM) candidate.PL.(DAT)

engagiert dienen, und Marion hofft das auch.

committedly serve.3PL and Marion laments it too

'Joachim hopes that consultants committedly serve candidates, and Marion hopes so, too.'

(24) a: inanimate-accusative

Lily sagt, dass Patienten Anweisungen

Lily says that patient.PL.(NOM) instruction.PL.(ACC)

ungern missachten und Emma sagt das gleiche.

reluctantly disobey.3PL and Emma says the same

'Lily says that patients are reluctant to disobey instructions, and Emma says so, too.'

b: animate-accusative

Helene sagt, dass Patienten ürztinnen ungern

Helene says that patient.PL.(NOM) doctor.FEM.PL.(ACC) reluctantly

missachten und Simon sagt das gleiche.

disobey.3PL and Simon says the same

'Helene says that patients are reluctant to disobey doctors, and Simon says so, too.'

c: inanimate-dative

Janne sagt, dass Patienten Anweisungen

Janne says that patient.PL.(NOM) instruction.PL.(DAT)

ungern gehorchen und Ingo sagt das gleiche.

reluctantly obey.3PL and Ingo says the same

'Janne says that patients are reluctant to obey instructions, and Ingo says so, too.'

$\mathrm{d}$ : animate-dative

Silke sagt, dass Patienten Ärztinnen

Silke says that patient.PL.(NOM) doctor.FEM.PL.(DAT)

ungern gehorchen und Wolfgang sagt das gleiche.

reluctantly obey.3PL and Wolfgang says the same

'Silke says that patients are reluctant to obey doctors, and Wolfgang says so, too.'

(25) a: inanimate-accusative

Vera glaubt, dass Fußballfans Sportsendungen

Vera believes that football.fan.PL.(NOM) sport.broadcast.PL.(ACC) 
ungeduldig herbeisehnen und Kai glaubt es auch.

impatiently yearn.for.3PL and Kai believes it too

'Vera believes that football fans impatiently yearn for sports programmes, and Kai believes so, too.'

b: animate-accusative

Ingo glaubt, dass Fußballfans Schiedsrichterinnen

Ingo believes that football.fan.PL.(NOM) referee.FEM.PL.(ACC)

ungeduldig herbeisehnen und Dan glaubt es auch.

impatiently yearn.for.3PL and Dan believes it too

'Ingo believes that football fans impatiently yearn for referees, and Dan believes so, too.'

c: inanimate-dative

Nadia glaubt, dass Fußballfans Sportsendungen

Nadia believes that football.fan.PL.(NOM) sport.broadcast.PL.(DAT)

ungeduldig entgegenfiebern und Mara glaubt es auch.

impatiently fever.toward.3PL and Mara believes it too

'Nadia believes that football fans impatiently look forward to sports programmes, and Mara believes so, too.'

$\mathrm{d}$ : animate-dative

Leo glaubt, dass Fußballfans Schiedsrichterinnen

Leo believes that football.fan.PL.(NOM) referee.FEM.PL.(DAT)

ungeduldig entgegenfiebern und Niki glaubt es auch.

impatiently fever.toward.3PL and Niki believes it too

'Leo believes that football fans impatiently look forward to referees, and Niki believes so, too.'

(26) a: inanimate-accusative

Markus findet, dass Menschen Maschinen irgendwie

Markus thinks that human.PL.(NOM) machine.PL.(ACC) somehow mögen, und Nina findet das auch.

like.3PL and Nina thinks that too

'Markus thinks that humans kind of like machines, and Nina thinks so, too.'

b: animate-accusative

Roland findet, dass Menschen Affen irgendwie

Roland thinks that human.PL.(NOM) monkey.PL.(ACC) somehow mögen, und Martin findet das auch.

like.3PL and Martin thinks that too

'Roland thinks that humans kind of like monkeys and Martin thinks so, too.' 
c: inanimate-dative

Silke findet, dass Menschen Maschinen irgendwie

Silke thinks that human.PL.(NOM) machine.PL.(DAT) somehow ähneln und Astrid findet das auch.

resemble.3PL and Astrid thinks that too

'Silke thinks that humans somehow resemble machines, and Astrid thinks so, too.'

$\mathrm{d}$ : animate-dative

Bert findet, dass Menschen Affen irgendwie

Bert thinks that human.PL.(NOM) monkey.PL.(DAT) somehow

ähneln und Ingo findet das auch.

resemble.3PL and Ingo thinks that too

'Bert thinks that humans somehow resemble monkeys, and Ingo thinks so, too.'

(27) a: inanimate-accusative

Florian sagt, dass Demonstranten Polizeiwagen

Florian says that protester.PL.(NOM) police.van.PL.(ACC)

stundenlang beobachten und Julia sagt das auch.

hour.long observe.3PL and Julia says that too

'Florian says that protesters observe police vans for hours, and Julia says so, too.'

b: animate-accusative

Felix sagt, dass Demonstranten Polizistinnen

Felix says that protester.PL.(NOM) police.FEM.PL.(ACC)

stundenlang beobachten und Lisa sagt das auch.

hour.long observe.3PL and Lisa says that too

'Felix says that protesters observe policewomen for hours, and Lisa says so, too.'

c: inanimate-dative

Lukas sagt, dass Demonstranten Polizeiwagen

Lukas says that protester.PL.(NOM) police.van.PL.(DAT)

stundenlang gegenüberstehen, und Tanja sagt das auch.

hour.long stand.opposite.3PL and Tanja says that too

'Lukas says that protesters face policevans for hours, and Tanja says so, too.'

$\mathrm{d}$ : animate-dative

Tim sagt, dass Demonstranten Polizistinnen

Tim says that protester.PL.(NOM) police.FEM.PL.(DAT) 
stundenlang gegenüberstehen, und Björn sagt das auch. hour.long stand.opposite.3PL and Björn says that too 'Tim says that protesters face policewomen for hours, and Björn says so, too.'

(28) a: inanimate-accusative

Mellie kritisiert, dass Eltern Anschuldigungen

Melli criticizes that parent.PL.(NOM) accusation.PL.(ACC)

zögerlich anerkennen, und Basti kritisiert das auch.

hesitantly recognize.3PL and Basti criticizes that too

'Melli criticizes that parents hesitantly recognize accusations, and Basti criticizes that, too.'

b: animate-accusative

Christian kritisiert, dass Eltern Lehrerinnen zögerlich

Christian criticizes that parent.PL.(NOM) teacher.PL.(ACC) hesitantly anerkennen, und Birte kritisiert das auch.

recognize.3PL and Birte criticizes that too

'Christian criticizes that parents hesitantly recognize teachers, and Birte criticizes that, too.'

c: inanimate-dative

Anne kritisiert, dass Eltern Anschuldigungen zögerlich

Anne criticizes that parent.PL.(NOM) accusation.PL.(DAT) hesitantly

beipflichten, und Flo kritisiert das auch.

assent.3PL and Flo criticizes that too

'Anne criticizes that parents hesitantly assent to accusations, and Flo criticizes that, too.'

$\mathrm{d}$ : animate-dative

Andi kritisiert, dass Eltern zehrerinnen zögerlich

Andi criticizes that parent.PL.(NOM) teacher.PL.(DAT) hesitantly

beipflichten, und Robert kritisiert das auch.

assent.3PL and Robert criticizes that too

'Andi criticizes that parents hesitantly assent to teachers, and Robert criticizes that, too.'

(29) a: inanimate-accusative

Ina hofft, dass Ärztinnen Versicherungen besonders

Ina hopes that doctor.FEM.PL.(NOM) insurance.PL.(ACC) specifically

empfehlen, und Pia hofft das auch.

recommend.3PL and Pia hopes that too 
'Pia hopes that doctors specifically recommend insurance companies, and Pia hopes that, too.'

b: animate-accusative

Ina hofft, dass Ärztinnen Krankenschwestern besonders

Ina hopes that doctor.FEM.PL.(NOM) nurse.PL.(ACC) specifically

empfehlen, und Till hofft das auch.

recommend.3PL and Till hopes that too

'Pia hopes that doctors specifically recommend nurses, and Pia hopes that, too.'

c: inanimate-dative

Tim hofft, dass Ärztinnen Versicherungen besonders

Tim hopes that doctor.FEM.PL.(NOM) insurance.PL.(DAT) specifically vertrauen und Isa hofft das auch.

trust.3PL and Isa hopes that too

'Pia hopes that doctors specifically recommend nurses, and Pia hopes that, too.'

$\mathrm{d}$ : animate-dative

Mia hofft, dass Ärztinnen

Krankenschwestern besonders

Mia hopes that doctor.FEM.PL.(NOM) nurse.PL.(DAT) specifically

vertrauen und Ali hofft das auch.

trust.3PL and Ali hopes that too

'Mia hopes that doctors especially trust nurses, and Ali hopes that, too.'

(30) a: inanimate-accusative

Paula glaubt, dass Journalisten Drohungen einfach

Paula believes that journalist.PL.(NOM) threat.PL.(ACC) simply

ignorieren, und Daniel glaubt das auch.

ignore.3PL and Daniel believes that too

'Paula believes that journalists simply ignore threats, and Daniel believes that, too.'

b: animate-accusative

Felix glaubt, dass Journalisten Konkurrenten einfach

Felix believes that journalist.PL.(NOM) competitor.PL.(ACC) simply

ignorieren, und Dora glaubt das auch.

ignore.3PL and Dora believes that too

'Felix believes that journalists simply ignore competitors, and Dora believes that, too.'

c: inanimate-dative

Hermann glaubt, dass Journalisten Drohungen einfach

Hermann believes that journalist.PL.(NOM) threat.PL.(DAT) simply 
nachgeben, und Inge glaubt das auch. give.in.to.3PL and Inge believes that too 'Hermann believes that journalists simply give in to threats, and Inge believes that, too.'

$\mathrm{d}$ : animate-dative

Ingo glaubt, dass Journalisten Konkurrenten einfach Ingo believes that journalist.PL.(NOM) competitor.PL.(DAT) simply nachgeben, und Sabine glaubt das auch. give.in.to.3PL and Sabine believes that too 'Ingo believes that journalists simply give in to competitors, and Sabine believes that, too.'

(31) a: inanimate-accusative

Tom vermutet, dass Politikerinnen Entwicklungen

Tom suspects that politician.FEM.PL.(NOM) development.PL.(ACC)

heimlich ausspionieren, und Till vermutet das auch.

secretly give.in.to.3PL and Till suspects that too

'Tom suspects that politicians secretly spy on developments, and Tiom suspects that, too.'

b: animate-accusative

Paula vermutet, dass Politikerinnen

Kolleginnen

Paula suspects that politician.FEM.PL.(NOM) colleague.FEM.PL.(ACC)

heimlich ausspionieren, und Dan vermutet das auch.

secretly give.in.to.3PL and Dan suspects that too

'Paula suspects that politicians secretly spy on colleagues, and Dan suspects that, too.'

c: inanimate-dative

Horst vermutet, dass Politikerinnen Entwicklungen

Horst suspects that politician.FEM.PL.(NOM) development.PL.(DAT)

heimlich nachhelfen, und Karin vermutet das auch.

secretly help.along.3PL and Karin suspects that too

'Horst suspects that politicians secretly help along developments, and Karin suspects that, too.'

$\mathrm{d}$ : animate-dative

Marion vermutet, dass Politikerinnen Kolleginnen

Marion suspects that politician.FEM.PL.(NOM) colleague.FEM.PL.(DAT)

heimlich nachhelfen, und Vera vermutet das auch.

secretly help.along.3PL and Vera suspects that too

'Marion suspects that politicians secretly help along colleagues, and Vera suspects that, too.' 
(32) a: inanimate-accusative

Horst glaubt, dass Rockstars Sekten gründlich

Horst believes that rockstar.PL.(NOM) cult.PL.(ACC) thoroughly

verabscheuen, und Schorsch glaubt das auch.

despise.3PL and Schorsch believes the same

'Horst believes that rockstars thoroughly despise cults, and Schorsch believes the same.'

b: animate-accusative

Dieter glaubt, dass Rockstars Gurus gründlich

Dieter believes that rockstar.PL.(NOM) guru.PL.(ACC) thoroughly

verabscheuen, und Sabrina glaubt das auch.

despise.3PL and Sabrina believes the same

'Dieter believes that rockstars thoroughly despise gurus, and Sabrina believes the same.'

c: inanimate-dative

Petra glaubt, dass Rockstars Sekten gründlich

Petra believes that rockstar.PL.(NOM) cult.PL.(DAT) thoroughly

verfallen, und Heidi glaubt das auch.

fall.for.3PL and Heidi believes the same

'Petra believes that rockstars thoroughly fall for cults, and Heidi believes the same.'

$\mathrm{d}$ : animate-dative

Maria glaubt, dass Rockstars Gurus gründlich

Maria believes that rockstar.PL.(NOM) guru.PL.(DAT) thoroughly

verfallen, und Hans glaubt das auch.

fall.for.3PL and Hans believes the same

'Maria believes that rockstars thoroughly fall for gurus, and Hans believes the same.' 